\title{
Compulsory Voting, Turnout, and Government Spending: Evidence from Austria*
}

\author{
Mitchell Hoffman \\ University of Toronto
}

\author{
Gianmarco León \\ UPF and Barcelona GSE
}

\author{
María Lombardi \\ $\mathrm{UPF}$
}

September 2016

\begin{abstract}
We study a unique quasi-experiment in Austria, where compulsory voting laws are changed across Austria's nine states at different times. Analyzing state and national elections from 1949-2010, we show that compulsory voting laws with weakly enforced fines increase turnout by roughly 10 percentage points. However, we find no evidence that this change in turnout affected government spending patterns (in levels or composition) or electoral outcomes. Individual-level data on turnout and political preferences suggest these results occur because the impacts of compulsory voting on turnout are larger among those who are non-partisan, who have low interest in politics, and who are uninformed.
\end{abstract}

JEL Classifications: H10, D72, P16

Keywords: Compulsory voting, Fiscal policy, Incentives to vote

${ }^{*}$ Contact: Hoffman mitchell.hoffman@rotman.utoronto.ca, León: gianmarco.leon@upf.edu, Lombardi: maria.lombardi@upf.edu. We thank Sandro Ambuehl, Heski Bar-Isaac, Rene Boeheim, Kevin Bryan, Florian Ederer, Jeremy Ferwerda, Rui de Figueiredo, Fred Finan, Max Kasy, John Morgan, Gerard Roland, Peter Rosner, Francesco Trebbi, and seminar participants for helpful comments. Faisal Ibrahim, Melina Mattos, Nicholas Roth, and Dijana Zejcirovic provided outstanding research assistance. Hoffman acknowledges support from the Kauffman Foundation, the National Science Foundation IGERT Fellowship, and the Social Science and Humanities Research Council of Canada. León acknowledges support from the Spanish Ministry of Economy and Competitiveness, through the Severo Ochoa Programme for Centres of Excellence in R\&D (SEV-2011-0075) and grant ECO2014-55555-P. 


\section{Introduction}

Despite the centrality of elections to democracy, in elections around the world many people fail to vote. Many European countries have seen a steep decline in turnout rates in the past 30 years, with record low rates in the past two (2009 and 2014) elections for the European Parliament. ${ }^{1}$ Ethnic minorities, immigrants, and poor voters in Europe are significantly less likely to vote, potentially distorting the political process (e.g., Gallego, 2007). In the US, turnout also exhibits large disparities along socioeconomic and racial lines (e.g., Linz et al., 2007; Timpone, 1998). Such disparities in turnout are believed to cause disadvantaged groups to be under-served by government (e.g., Meltzer and Richard, 1981; Lijphart, 1997).

One policy to help address these issues is to make voting mandatory. As of 2008, 32 countries had a compulsory voting (CV) law in place (Chong and Olivera, 2008), and a higher number had CV at some point during the last 50 years. In March 2015, US President Barack Obama proposed the possibility of CV, arguing "If everyone voted, then it would completely change the political map of this country. The people who tend not to vote are young, they're lower income, they're skewed more heavily towards immigrant groups and minority groups...There's a reason why some folks try to keep them away from the polls." 2 However, there is limited empirical evidence about how CV affects turnout, party vote shares, and government policy.

We provide empirical evidence on the impact of CV laws on turnout, electoral outcomes, and fiscal policy using a unique natural experiment in Austria. Since World War II, Austria's nine states have changed their CV laws at different times for different types of elections. Austria provides a compelling case study for multiple reasons. First, the variation in CV laws is significant across states and over time, providing rich variation for quasi-experimental analysis. Second, like the US and many other countries, Austria exhibits socioeconomic disparities in turnout, with poor people being less likely to vote than the rich (Mahler et

\footnotetext{
${ }^{1}$ From http://www.europarl.europa.eu/elections2014-results/en/turnout.html, last accessed March 16, 2016.

${ }^{2}$ See, e.g., http://www.cnn.com/2015/03/19/politics/obama-mandatory-voting/, accessed March 16, 2016.
} 
al., 2014). In addition, as noted by Ferwerda (2014), with the exception of one Swiss canton (Vaud), Austria is the sole modern democracy to have within-country variation in CV for national elections.

Using state-level voting records on state and national elections from 1949-2010, we find that CV increases turnout from roughly $80 \%$ to $90 \%$. Impacts on turnout vary somewhat across the three types of elections (parliamentary, state, and presidential), but are sizable. Interestingly, however, CV does not appear to affect state-level spending. These "zero effects" are reasonably precisely estimated and robust to different specifications that deal with concerns regarding possible endogenous changes in CV laws.

How could it be that CV had large impacts on turnout, but did not affect policy outcomes? Our analysis shows that despite the large increase in turnout, CV did not affect electoral outcomes: vote shares for liberal parties did not change significantly, nor did the number of parties running for office or the victory margin in state or parliamentary elections.

To complement our main aggregate analysis and dig further into mechanisms, we use repeated cross sections of individual level data to analyze interaction effects of CV laws with voter characteristics. While our statistical power is more limited compared to our main analyses, we find suggestive evidence of larger CV impacts on turnout among women and those with lower income. Impacts also seem larger among those who have low interest in politics, who have no party affiliation, and who are relatively uninformed (as proxied by newspaper reading). While suggestive, these results are consistent with a story where voters who vote or abstain due to the introduction or repeal of CV do not have strong policy or partisan preferences (on average), thereby having little or no effect on electoral outcomes. Furthermore, if such voters are unresponsive to policy in deciding which party to support, parties may have little incentive to shape policies to suit those voters' preferences.

Our paper relates to three main literatures. First, an important literature analyzes how changes in turnout and electorate composition affect public policy (Persson and Tabellini, 2000), often looking at the impacts of enfranchising particular groups of people. For example, 
the enfranchisement of women in the US led to increases in government health expenditures (Miller, 2008), as did the adoption of electronic voting in Brazil, which effectively enfranchised illiterate voters (Fujiwara, 2015). Similarly, Naidu (2012) shows that post-Civil War laws restricting voting for blacks in the US South had sizable impacts on public policy. ${ }^{3}$ Our findings do not contradict this literature, but complement it, suggesting that the extent to which changes in turnout affect policy depends importantly on whether these policies affect a group of the population with specific policy preferences.

Second, our paper speaks to the literature on the determinants of voter turnout. As discussed in Gerber and Green (2012), scholars have analyzed numerous interventions aimed at increasing turnout, often using randomized experiments. In non-experimental studies, a significant literature examines the impact of voting costs, often reaching different results from different changes in costs. ${ }^{4}$ For example, Farber (2009) shows that election holidays and "time-off" have little impact on turnout in the US, whereas Brady and McNulty (2011) show that an increase in voting costs (due to unexpected changes in the location of polling stations) reduces turnout. We complement this literature by simultaneously analyzing turnout and government policy.

Two noteworthy recent studies follow this tradition, analyzing how changes in voting costs affect turnout and policy outcomes. Hodler et al. (2015) propose a model of government where higher-skill individuals are more likely to vote. A reduction in voting costs leads to some lower-skill individuals choosing to vote. On one hand, these lower-skill individuals like government spending because a greater share of it is paid for by the rich (Meltzer and

\footnotetext{
${ }^{3}$ Other papers in this literature show mixed results of the extension of the voting franchise on redistributive policies (e.g., Husted and Kenny, 1997; Rodriguez, 1999; Gradstein and Milanovic, 2004; Timpone, 2005; Cascio and Washington, 2014). A common message from this literature is that efforts to extend the voting franchise can significantly affect public policy, making it more aligned with voters' preferences. Most of this literature analyzes episodes in which groups with specific policy preferences are de jure or de facto enfranchised, leading elected officials to cater policies toward them.

${ }^{4}$ Weather shocks have been used as exogenous shifts in the cost of voting (e.g., Knack, 1994; Gomez et al., 2007; Hansford and Gomez, 2010; Fraga and Hersh, 2010; Gomez et al., 2007), as have general rules of governance (Hinnerich and Pettersson-Lidbom, 2014; Herrera et al., 2014), candidates' ethnicity (Washington, 2006), and availability of certain information technology (Stromberg, 2004; Enikolopov et al., 2010; Gentzkow, 2006; Gentzkow et al., 2011; Gavazza et al., 2014). Some of these voting cost shifters are unexpected shocks, whereas others could be anticipated by politicians.
} 
Richard, 1981). On the other hand, they invest less in political information than high-skill voters, making them more likely to be impressionable and thereby driven to choose candidates based on lobby-funded campaign spending instead of government spending. To test the model, they study the staggered introduction of postal voting across Swiss cantons. Postal voting led to increased turnout, lower education of participants, lower political information, and lower welfare spending. Godefroy and Henry (2015) analyze the impact of voting cost shocks on the selection of politicians and discretionary expenditures. Using digestive infections as a shock to voting costs, they find that unanticipated increases in voting costs lead to lower turnout, higher candidate quality, and higher infrastructure expenditures in French cities. We discuss differences between our results and these two studies in Section 4.2.

Third, it relates to a small but burgeoning literature analyzing CV. Among a number of theory papers, Börgers (2004) and Krishna and Morgan (2011) argue that CV reduces welfare, whereas Krasa and Polborn (2009) show that compulsory voting (or costly voting) allows an aggregation of preferences that can increase welfare. In empirical work, Funk (2007) finds that abolishing CV significantly decreased turnout in Switzerland despite the fact that fines were small and not enforced. Her results highlight the expressive value of $\mathrm{CV}$, an interpretation that could also apply to our setting, given the low levels of enforcement of the fines. However, this study does not investigate further the effects of changes in turnout on public policy. ${ }^{5}$ In a cross-country study, Chong and Olivera (2008) show that countries with CV have lower income inequality. Fowler (2013) exploits the staggered introduction of CV across Australian states, finding that CV led to large increases in turnout. De Leon and Rizzi (2014) analyze students in Brazil, where voting is voluntary between ages 16 to 18 , but mandatory afterward. They find that CV increases turnout, but does not affect political information. Using a field experiment in Peru providing information about changes in abstention fines, León (2015) shows that a reduction in the fines decreases turnout, and consistent with our findings, that the reduction

\footnotetext{
${ }^{5}$ Also focusing on Switzerland, in recent work contemporaneous with our own, Bechtel et al. (2016b) find that CV increases electoral support in referendums for leftist policy positions. Note, however, that Bechtel et al. (2016b) study voters' support for policies as opposed to the behavior/policies of representative government, which we study. Still using Switzerland, Bechtel et al. (2016a) find that CV does not lead to habit formation in voting.
} 
is driven by uninformed, uninterested, and centrist voters. However, León (2015) can only analyze policy preferences and cannot analyze actual policies as our paper does.

A few political science papers involve the specific case of CV in Austria. The first paper to explore it was Hirczy (1994), who compared overall voting rates between Austrian states over time; the graphical evidence presented suggests that adoption of CV led to significant increases in turnout. The paper closest (and contemporaneous) to ours is Ferwerda (2014), who analyzes the effects of the repeal of CV by the Austrian parliament in 1992 on turnout and on changes in party vote shares. Although his analysis period is much shorter, the magnitude of the effects found on electoral participation and party vote shares are broadly consistent with ours. ${ }^{6,7}$ Our paper goes beyond these studies in three main ways. First and foremost, not only do we analyze the political consequences of CV, but also impacts on spending, thereby providing the first micro study (for Austria or any other country) to examine how CV affects government spending. Second, we complement the analysis of aggregate data with individual level information on political preferences and voting behavior, allowing us to study the shift in the composition of the pool of voters resulting from CV. Finally, we analyze all elections from 1949-2010 instead of just a subset; this enables us to implement a fixed effects analysis allowing for different state linear trends, ruling out the concern that the effects are only valid in the short term and that we should expect a reversion to the mean.

Section 2 provides background on democratic institutions and CV in Austria. Section 3 describes the data. Section 4 discusses our estimation strategy and shows the results. Section 5 analyzes mechanisms for our results. Section 6 concludes and discusses external validity.

\footnotetext{
${ }^{6}$ Ferwerda (2014) also uses municipal-level data instead of state-level data.

${ }^{7}$ Another contemporaneous paper, Shineman (2014), also uses Austria as a case study to demonstrate the effects of $\mathrm{CV}$ on individual-level political sophistication, finding that both recent and long-term exposure to $\mathrm{CV}$ increase voters' information.
} 


\section{Institutional Background}

\subsection{Democratic Institutions and Budgeting Processes in Austria}

Austria is a federal and parliamentary democracy, composed of nine autonomous states. The National Parliament is composed of two chambers, the National Council (Nationalrat) and the Federal Council (Bundesrat), with legislative authority vested mostly in the former. National Council members are directly elected by proportional representation, whereas members of the Federal Council are elected by the state legislatures. Austria's executive branch is composed of the Federal President (Bundespräsident), the Federal Chancellor (Bundeskanzler), and the Federal Cabinet. The Federal President is elected by simple majority in a popular election, and the candidates are nominated by party coalitions. The president holds the mostly ceremonial position of head of state. The Federal Cabinet is composed of the Federal Chancellor (the head of government) and a group of ministers, all of whom are appointed by the president. Austrian states are ruled by their own regional parliament (Landtag), a state government (Landesregierung), and a governor (Landeshauptmann). State parliament representatives are directly elected. Unlike the federal government, state governors are elected by the state parliament.

Over 95\% of taxes in Austria are collected at the federal level (Blöndal and Bergvall, 2007). Taxes are distributed across the three levels of government (federal, state, and local) according to Fiscal Equalization Laws, which last for short periods of time ( $\sim 4$ years $)$ and are established by a consensus between the federal and regional governments (Blöndal and Bergvall, 2007). Within the two lower levels of government, tax revenues are distributed across the different units according to a formula, which takes into account demographic and revenue criteria. Federal transfers to state governments are classified into two broad categories:

(i) funds earmarked for a precise purpose and (ii) discretionary funds (1948 Constitutional Law, Sections II and III). ${ }^{8}$ Throughout our period of analysis, discretionary funds tended

\footnotetext{
${ }^{8}$ We use "discretionary" to refer to non-earmarked transfers. From the discussion in Lehner (1997), much of the earmarked funds are meant to be spent on wages, particularly wages of teachers. Earmarked funds are
} 
to account for about half of the total transfers (Lehner, 1997), giving state governments considerable fiscal autonomy. States' spending autonomy comes across in the substantial variation in state spending percentages on different budget categories. ${ }^{9}$ Although the largest portion of tax revenues are allocated to the central government, state governments receive a significant portion of the total budget, and are responsible for providing a wide array of public goods and services. In 2006, for example, spending by state governments accounted for $17 \%$ of total spending, with $70 \%$ and $13 \%$ of spending carried out by the central and municipal governments, respectively (IMF, 2008). State government responsibilities include primary education, regional infrastructure, hospitals, transportation, social welfare, and pensions for state civil servants (IMF, 2008). ${ }^{10}$

In the postwar period, there were two major parties in Austria, as well as several smaller parties. The two major parties were the center-right People's Party (ÖVP) and the centerleft Social Democratic Party (SPÖ). In addition, there were the right-wing populist Freedom Party of Austria (FPÖ), the Communist Party of Austria (KPÖ), and the Green Party, as well as the Alliance for the Future of Austria, the Liberal Forum, and others.

\subsection{Compulsory Voting in Austria}

Figure 1 summarizes the process by which CV was introduced and later repealed in Austria. The mandate to vote was changed a number times during 1949-2010; whether voting was compulsory varied substantially both across and within states, and depending on the type of election, as seen in Figure 2. CV was first introduced in Austria in the 1929 Constitution. In particular, voting became mandatory for all citizens in presidential elections, but it was up

also used for infrastructure expenses, housing subsidies, residential dwelling projects, local transport, disaster control, environmental/agricultural expenses, and health.

${ }^{9}$ During 1980-2012, for example, the government of Burgenland devoted $66 \%$ of its budget to welfare expenditures and only $13 \%$ to infrastructure spending, whereas the neighboring state of Lower Austria spent $43 \%$ of its resources on welfare, and $40 \%$ on infrastructure. Section 3 describes the budget categories further.

${ }^{10}$ In some of these areas, the responsibilities of the central and state governments overlap and are thus cofinanced or managed jointly (IMF, 2008). There is also overlap of responsibilities between state and municipal governments (IMF, 2008). OECD (1997) notes for Austria that "the revenue-sharing process is rather complex" (pp. 99-100). For further details on state spending, see Appendix C. 
to each state to determine whether voting was mandatory or voluntary in parliamentary and state elections (see Appendix B.1 for further details).

The first presidential election with CV was held in 1951. Up until 1980, there were seven presidential elections, and all of them had CV. However, a 1982 amendment to the Austrian Constitution made voting in presidential elections compulsory only in the states that decided so. In the 1986 presidential elections, the states of Vorarlberg, Tyrol, Styria, and Carinthia decided to keep CV. Furthermore, Carinthia enacted a law establishing CV for parliamentary and state elections. The remaining five states abolished CV in presidential elections after the 1982 amendment.

In 1992, a Federal Constitution amendment by the national parliament withdrew the power of establishing mandatory voting in the national parliament elections from the states (Federal Law Gazette No. 470/1992). Starting in the 1994 parliamentary elections, voting was optional in all states. After this constitutional amendment, the states which still had CV in presidential and state parliament elections started repealing their state laws one by one. In 1993, Carinthia and Styria eliminated CV for both types of elections. Tyrol repealed CV for state parliament elections in 2002, and Vorarlberg got rid of it before the 2004 elections. After these elections, Tyrol finally repealed CV for presidential elections. Thus, the 2010 presidential elections (the last in our sample) were the first in which voting was voluntary throughout the country.

During the period when voting was compulsory, local authorities were responsible for issuing fines against non-voters failing to provide a reasonable excuse for abstaining. ${ }^{11} \mathrm{Ab}-$ stention penalties were extremely rare, as the law allowed for a wide range of excuses for not voting, such as illnesses, professional commitments, urgent family matters, being outside the state during the election, or "other compelling circumstances" due to which the voter could not go to the polls. Importantly, voters who excused themselves were not required to pro-

\footnotetext{
${ }^{11}$ Federal Presidential Election Law, Article 23 and Federal Parliament Election Law, Article 105 (4). We provide details on the maximum fine amounts specified in the law and their evolution in different states in Appendix B.2. While there is information on maximum fine amounts in states, we have limited information on actual fine amounts (for the cases where fines were actually enforced), due to the involvement of local authorities in setting actual fines.
} 
vide documentation justifying their absence. ${ }^{12}$ After qualitative work with Austrian citizens and elites, Shineman (2014) concludes that fines rarely had real consequences and were almost never enforced. Appendix B.2 gives additional details supporting that fines were weakly enforced.

\section{Data Sources and Descriptive Statistics}

In the empirical analysis, we draw upon three main sources of information. First, to analyze how CV affects turnout and political competition, we collected election data. Our initial sample consists of all parliamentary, presidential, and state elections held since the end of World War II until 2010. ${ }^{13}$ For these elections, we hand-collected data on voter turnout, invalid ballots and party vote shares from the Austrian Federal Ministry of the Interior's yearbooks. We define turnout as the share of registered voters who show up to the polls. ${ }^{14}$

Table 1 gives descriptive statistics. Average turnout in our sample is relatively high, ranging from $86 \%$ in state elections to $90 \%$ in parliamentary elections. The average incidence of invalid ballots in these elections is $2 \%$. We define "right-wing" parties as ÖVP and FPÖ and "left-wing" parties as SPÖ and KPÖ. ${ }^{15}$ Both in state and parliamentary elections, the right-wing vote share (52\%-53\%) exceeds the left-wing vote share (around $40 \%$ ).

Second, to analyze spending, we draw upon detailed annual information on expendi-

\footnotetext{
${ }^{12}$ Abstainers needed to provide evidence of reasons for not voting only when an administrative penal procedure was initiated against them. Appendix B.2 provides further details on abstention sanctions.

${ }^{13}$ We exclude the 1945 election. This election was unusual in multiple respects, coming just after World War II and banning former Nazis (about one-tenth of the voting age population) who were not allowed to vote until the 1949 election (Bischof and Plasser, 2008). In the period under consideration, there were 19 parliamentary elections, 12 presidential elections, and around 11-15 state elections in each of the nine Austrian states.

${ }^{14}$ As discussed by Geys (2006), studies of turnout have used different denominators in defining turnout, including voting age population, eligible voters, and registered voters. Geys (2006) argues that there is no single correct measure of turnout, but that using eligible voters is preferred over voting age population when data on eligible voters are available, since it excludes those who are legally forbidden from voting (Geys, 2006, p. 639). For Austria, registration is automatic for all citizens with a permanent residence in the country; thus, "registered voters" and "eligible voters" are approximately equivalent in Austria. In addition, we prefer using registered voters over voting age population because we were only able to gather state-specific voting age population data beginning in 1982. Finally, an advantage of using registered voters is that the data are based on administrative registration records.

${ }^{15}$ Appendix $\mathrm{C}$ gives further discussion and details on this grouping.
} 
tures by each of the state governments, which is publicly available on the Austrian Statistical Agency's website. Unfortunately, this information is only available since $1980 .{ }^{16}$ The Austrian Statistical Agency expenditure data include 10 expenditure groupings by year. To simplify exposition and improve statistical precision, we combined the groupings into three broad categories: Administrative, Welfare, and Infrastructure. We define "administrative expenditures" as spending on elected representatives and general administration. "Welfare Expenditures" comprise expenditures on education; health; arts and culture; and social welfare and housing. "Infrastructure Expenditures" are those for construction, transport, and security. ${ }^{17}$ The yearly expenditure data is expressed in millions of 2010 euros. In the 1980-2012 period, a majority of expenses (54\%) were devoted to the social sector, while $25 \%$ of all resources were spent on administration, and the remaining $21 \%$ were devoted to infrastructure. In all of our main specifications, we also include state-specific, time-varying covariates (i.e., total population and unemployment rates) obtained from the Austrian Statistical Agency.

Third, to analyze heterogeneity in CV turnout effects according to individual characteristics, we use the Austrian Social Survey (ASS), a nationally representative survey conducted in 1986, 1993, and 2003. The 1993 round did not include questions on turnout, so we exclude it from our analysis. Haller et al. (1987) and Haller et al. (2005) give details on the 1986 and 2003 rounds. The ASS asks respondents standard questions on demographics, socioeconomic status, education, and importantly, it inquires about voting behavior, and political and social preferences. Table 2 shows summary statistics from our individual level data. ${ }^{18}$

\footnotetext{
${ }^{16}$ This restricts our analysis to 10 parliamentary elections, 6 presidential elections and 6-7 state elections in each state. In Appendix Table A.3, we repeat our main results on turnout, invalid votes and political competition for the restricted period of 1979-2010, and they are qualitatively similar to those in the main text covering 1949-2010.

${ }^{17}$ Table A.1 provides a detailed description of expenditure areas falling into each of the 10 groupings. Our conclusions are substantively unchanged if we analyze the 10 groupings individually.

${ }^{18}$ Our sample restricts to individuals (i) who were of voting age in the previous parliamentary elections and (ii) who reported whether or not they voted in the previous parliamentary elections. Only $3 \%$ of people failed to provide information about whether they voted, and missingness is not correlated with whether there is CV in their state. In the 1980 s, people were allowed to vote if they were 19 or older, while the voting age was lowered to 18 in 1992 (Kritzinger et al., 2013). For analysis of the ASS data, we do not restrict the sample based on voter eligibility because information on voter eligibility is absent from the 2003 wave. Thus, the turnout denominator (voting age population, which is 19 or older in the 1986 round and 18 or older in the 2003 round) in our analysis of the ASS data (presented later in Table 6) differs slightly from the one used in our main turnout results (Table 3). Our main focus in the heterogeneity analysis is on differences across
} 


\subsection{Comparing Austria to Other Countries}

Before providing our results, we seek to provide context by comparing Austria to other countries in terms of political behavior. Figure 3 compares turnout rates in Austria and other OECD countries. While Austria has high turnout, it is not an extreme outlier and there are a number of other countries with broadly similar turnout levels. While the median turnout in this sample is $75.7 \%$, turnout in Austrian parliamentary (state) elections when voting was voluntary is $83.8 \%(77.5 \%)$, which places these elections in the $76^{\text {th }}\left(56^{\text {th }}\right)$ percentile of the turnout distribution. ${ }^{19}$

Table A.2 compares Austria to other rich countries on three non-turnout measures of political engagement: interest in politics, information acquisition (proxied by newspaper reading), and political party membership. Austrians are politically engaged, but seem broadly similar to other rich countries. In the 2003 ASS, $26 \%$ of Austrians reported being "Very Interested in Politics," which is comparable with Switzerland (26.6\%) or Germany (21\%), but slightly higher than other OECD countries participating in the World Value Survey. ${ }^{20}$ While $68.7 \%$ of Austrians in the ASS read the newspaper regularly, $74.8 \%$ of people from other OECD countries in the World Value Survey report having read the newspaper the week before they were surveyed. The level of information acquisition in Austria is below countries like Switzerland (91.3\%), Sweden (94.5\%), or Japan (88.8\%), and only above less developed democracies like Hungary (56.8\%), Poland (55.1\%), or Spain (62.7\%). Likewise, 12.4\% of Austrians are members of a political party, comparable to $13.4 \%$ of respondents in other OECD countries. These statistics provide reassurance that our results seem unlikely to be due to an unusual institutional context or by political behaviors that are highly specific to Austria.

subgroups, so this should not be a central concern. Further, the Table 3 results are similar whether registered voters or voting age population is used as the denominator.

${ }^{19}$ The percentile numbers are calculated relative to elections with voluntary voting between 1979 and 2010 for the OECD countries in Figure 3. Being in the 76th percentile means that average turnout in Austrian parliamentary elections is higher than turnout in $76 \%$ of OECD elections. The state election percentile should be taken with some care because it reflects a comparison of state elections in Austria to national elections in other countries. In Figure 3, turnout is defined as a percentage of registered voters.

${ }^{20}$ Note that Austria did not participate in the WVS, so the numbers are not strictly comparable, but they do give us a broad sense of how Austrians' political opinions compare to other countries. 


\section{Empirical Strategy and Results}

We estimate the effect of CV laws (in different elections) on turnout, invalid ballots, electoral outcomes, and state-level public spending. Using a difference-in-difference model, we compare states with and without CV at different points in time. Our baseline specification is:

$$
y_{s t}=\alpha_{0}+\beta_{1} C V_{s t}+X_{s t} \beta_{2}+\delta_{s}+\nu_{t}+\gamma_{s t}+\epsilon_{s t}
$$

where $y_{s t}$ is an outcome variable in state $s$ and year/election $t ;{ }^{21} C V_{s t}$ is a dummy for whether voting was compulsory in year/election $t$ and state $s ; X_{s t}$ is a vector of state-year covariates (population and the unemployment rate); $\delta_{s}$ are state fixed effects; $\nu_{t}$ are year fixed effects; $\gamma_{s t}$ are state-specific linear trends (at the election level); and $\epsilon_{s t}$ is an error. We run these regressions separately for different types of elections (parliamentary, state, and presidential). We also do a pooled specification including the three types of elections together - when we do this, we also include election type dummies, as well as all three sets of state-specific trends.

We allow for arbitrary within-state correlation of the errors by clustering our standard errors at the state level. Given the small number of clusters, our standard errors might be inconsistently estimated (Bertrand et al., 2004). Following Cameron et al. (2008), we also report wild-bootstrap p-values. ${ }^{22}$

In these specifications, our "treatment group" are statesXelectoral periods subject to CV, while the "control group" comprises those in which there is voluntary voting (VV). At any given period in time, we compare states under CV vs. VV (leveraging the time fixed effects), and at the same time, we make within-state comparisons, comparing electoral terms with and without CV (using state fixed effects). Using state level data, we analyze the effect of CV on: (i) turnout and valid ballots; (ii) left/right vote shares, number of parties, vote shares and

\footnotetext{
${ }^{21}$ For the case of government expenditures, the timing of the dependent variable is slightly different. We analyze spending as a function of $\mathrm{CV}$ in the current "electoral period" with a one year lag. We define an electoral period as lasting from the year of an election until the year before the next election. Thus, for example, if elections takes place in years $t$ and $t+4$, we consider expenditures in years $t+1$ to $t+4$ as a function of $\mathrm{CV}$ in year $t$. The idea is that the potential impact of $\mathrm{CV}$ on spending may come through elections, and we want to allow an election to take place in order to allow the possible consequences of CV on spending to occur. Also, for our spending analysis, the state-specific trends are by year instead of by election.

${ }^{22}$ We calculated the wild-bootstrap p-values using the cgmwildboot program created by Judson Caskey, and imposed the null hypothesis, as recommended by Cameron et al. (2008).
} 
margin of victory of the winning party; and (iii) government expenditures in social services, administration, and infrastructure. For (i) and (ii), the unit of analysis is stateXelection; when analyzing the impact of $\mathrm{CV}$ on expenditures, the unit of analysis is a stateXyear.

\subsection{Turnout and Invalid Votes}

Even with weak enforcement, as is the case for Austria, CV can affect turnout through the signaling value of enacting a law, as argued in Funk (2007). Panel A in Table 3 shows the effects of CV on turnout within and across Austrian states in the 1949-2010 period. The introduction of $\mathrm{CV}$ causes statistically and economically significant increases in turnout in parliamentary, state, and presidential elections.

When independently considering each type of election, we find that CV increases turnout by 6.5 percentage points in parliamentary elections, by 17.2 percentage points in state elections, and by 9.5 percentage points in presidential elections. However, we gain additional power by pooling all types of elections together, as doing so allows more precise estimation of the year and state fixed effects. In column 4 of Panel A in Table 3, we pool the three types of elections together, and analyze the impact of CV on each type of election (our preferred specification). CV now increases turnout by $6.6,8.1$, and 9.1 percentage points for parliamentary, state, and presidential elections, respectively. Note that these results show slightly lower point estimates than in the previous regressions, and this is particularly the case for state elections, for which we have a smaller sample size. The results are highly significant based on standard errors clustered by state (in parentheses) or based on wild bootstrap p-values (in brackets). ${ }^{23}$

$\mathrm{CV}$ can increase turnout by drawing uninterested voters, or those who might not be familiar with the voting process. If this is the case, we might expect the proportion of invalid ballots to rise. As shown in Panel B of Table 3, the increase in turnout from CV is paired with a statistically significant increase in invalid votes. In elections without CV, the share of

\footnotetext{
${ }^{23}$ Note that the wild bootstrap procedure does not deliver bootstrapped standard errors, but rather p-values. The p-values found using the clustered standard errors and the wild bootstrap procedure are generally similar in most cases. Throughout the paper, for ease of exposition, our interpretation of confidence intervals is based on the clustered standard errors.
} 
invalid votes ranges between $1.5 \%$ and $3.8 \%$. Based on the results in the preferred specification (column 4), CV increases the share of invalid votes by 0.9-1.8 percentage points, depending on the type of election. Even though the increase in turnout associated with CV is also conducive to a higher proportion of invalid votes, there is certainly not a one-to-one relation. That is, for every 10 people who are driven to vote due to $\mathrm{CV}$, only $1.5-3$ of them issue an invalid ballot, while the others correctly vote for a party or candidate. Hence, an increase in turnout of this magnitude could very well result in a shift in election results and public policies. ${ }^{24}$

\subsection{Public Spending}

An increase in participation rates could potentially affect government spending in multiple ways. If preferences for public goods in the participating electorate are now different, the government might change the distribution of public spending, keeping the size of the overall budget constant, but shifting it between sectors. Alternatively, the overall size of the budget could change by pushing the local government or local parliamentarians to change deficits or to negotiate larger budgets from the federal government.

As discussed in Section 2.1, given the ceremonial role of the federal president in Austria, we do not expect to see effects of CV in presidential elections on spending - as a placebo test, we run regressions estimating the effect of $\mathrm{CV}$ in presidential elections on fiscal behavior at the state level, and as expected, we do not find any effects (Appendix Table A.4). On the other hand, the national parliament decides on the resources that each state government gets. In addition, state parliaments are in charge of preparing the state's budget, and thus laws that affect this level of government may also affect spending. In this section, we turn our attention to the effects of CV on fiscal policy at the state level.

In the subsequent analysis, we study total state expenditures, as well as their composition: administrative, welfare, and infrastructure expenditures. For each spending category,

\footnotetext{
${ }^{24}$ Given that the analysis of the effects of $\mathrm{CV}$ on fiscal behavior is performed only for those years for which expenditure data is available (1979-2010), we re-run the analysis from Table 3 on a comparable sample in Appendix table A.3. The results shown for turnout and invalid votes are comparable to the ones for 1949-2012.
} 
we analyze three different measures of fiscal policy, which are intended to capture the different mechanisms described above: (i) the log levels, (ii) the log per-capita, and (iii) as a percentage of the total budget. We use a similar estimation framework as in Section 4.1.

Table 4 shows no consistent evidence of CV affecting the amount or composition of public spending. Most coefficients are close to zero, and the clustered standard errors as well as the wild-bootstrap p-values indicate that there is no significant relationship between $\mathrm{CV}$ and total budget or its composition. Across the 12 regressions in Panel A of Table 4, the coefficients are sometimes positive and sometimes negative, but small in magnitude. They are also relatively precise. For example, the estimated coefficient in column 1 on total spending corresponds to a $95 \%$ confidence interval of $[-0.009,0.071]$, meaning we can reject that CV decreases total spending in more than $0.9 \%$ or that it increases it by more than about $7.1 \%$. Similarly, the point estimates on administrative, welfare, and infrastructure spending are relatively close to zero, at $0.6 \%, 3.5 \%$, and $6.6 \%$, respectively. ${ }^{25}$ In contrast, electronic voting in Brazil (Fujiwara, 2015, p.452) and US women's suffrage (Miller, 2008, p.1289) are estimated to have each raised health spending by about one-third.

Our result on public spending contrast with those of Hodler et al. (2015) and Godefroy and Henry (2015). Consistent with a model where decreases in voting costs increase the share of voters who are uninformed, Hodler et al. (2015) find that Swiss postal voting decreased welfare spending by $4-7 \%$ and business taxation by $3-7 \%$. Why might our result differ? First, there are various political differences between Switzerland and Austria, including that Switzerland has much lower turnout (though other levels of political involvement and interest do not seem so different). For example, following the idea of the model of Hodler et al. (2015), it could be that there are few "impressionable" voters for politicians to take advantage of in Austria, and this could limit whether there are impacts on spending. Second, postal voting

\footnotetext{
${ }^{25}$ Besides using the 3 broad expenditure categories, we also do the analysis using the 10 more disaggregated groupings in Appendix Tables A.5 and A.6. Given the more granular level of the data, some of the confidence intervals are relatively large (e.g., for finance and service expenditures). However, the conclusions are qualitatively robust, with coefficients mostly statistically insignificant and close to zero. Further, our zero results are also qualitatively robust under an instrumental variable approach, where we estimate the effect of turnout (instrumented by CV) on expenditures (Appendix Table A.7).
} 
and CV may have different impacts on a political system. It is not clear that the population of voters who would respond to $\mathrm{CV}$ are the same as those would respond to postal voting. Even if both populations seem more uninformed on average, they may differ on unobservables. We note, though, that these explanations are speculative and cannot fully resolve why there are differences across papers. Further research is needed. ${ }^{26}$

Godefroy and Henry (2015) show that a decrease in turnout in French cities due to more digestive infections decreases harmful financial decisions, and leads to higher subsidies obtained by the municipality and more infrastructure expenditure, and they argue that this is due to the selection of better qualified politicians. In our paper, it is difficult to test this hypothesis directly because we do not observe direct information on the quality of politicians (such as whether a mayor contracted a toxic loan, which is observed by Godefroy and Henry (2015)). In addition, in contrast to us, Godefroy and Henry (2015) study unanticipated, unknown-in-advance shocks to voting cost.

\subsection{Robustness Checks}

The identification assumption in our main regressions is that CV is uncorrelated with unobserved time-varying state characteristics once we have controlled for time invariant, statespecific factors, as well as year-specific, state invariant factors, and partialled out state-specific linear time trends. For example, if conservative states are more likely to support CV, this should be absorbed by our state fixed effects. On the other hand, if there is a national push for abolishing these types of laws (e.g., in 1982), this would be captured by the year fixed effects. One threat to our identification assumption is that, even though some of the changes in CV laws were issued by the federal parliament (e.g., the 1992 repeal of CV in parliamentary elections), and thus are unlikely to respond to state-specific political dynamics, others changes

\footnotetext{
${ }^{26}$ There are a number of other potentially significant political differences between Switzerland and Austria. These include that Swiss cantons seem more powerful than Austrian states (e.g., unlike Swiss cantons, Austrian states do not have significant tax powers (Fuentes et al., 2006)); that Austria is more linguistically homogeneous; and that Switzerland and Austria have different historical experiences with democracy (e.g., Austrian politics has often emphasized consensus (Kritzinger et al., 2013)).
} 
were issued at the state level, and these decisions might be related to voting trends. As in any difference-in-difference model, this is the same as assuming that, conditional on the set of observables and fixed effects, the trends in voting, political competition, and expenditures in states in which CV was introduced were the same as in states where voluntary voting was in place; if the new voting regime had not been enacted, e.g., they have parallel trends in the pre-treatment period.

The parallel trends assumption would be violated if the states most likely to implement CV were those in which turnout was downward trending. In this case, an estimation relying on simple fixed effect will understate the effect of CV laws. Similarly, state governments might find it easier to enact CV laws when turnout is trending upward, since enforcement costs will be lower in these states. In this case, a fixed effects model would overestimate the results. The inclusion of state-specific time trends controls for any linear trends in our outcome variables, and thus partially addresses these concerns, but further tests are needed.

As mentioned in Section 2.2, in our study period there is one change in CV laws that is unrelated to any state-year specific characteristic, namely, the one introduced by the federal government in 1992. ${ }^{27}$ This Federal Constitution amendment withdrew the prerogative of establishing mandatory voting in the national parliament elections from the states. Effectively, while some states already had voluntary voting in parliamentary elections, others (Vorarlberg, Styria, Tyrol and Carinthia) were forced to adopt it. Figure 4 shows the evolution of turnout, invalid votes, and total, administrative, welfare, and infrastructure expenditures in the same analysis period (1986-2011), for states that never had CV and those that were mandated to eliminate it in 1992. States that had CV before 1992 had higher turnout and more invalid ballots, but importantly, before $\mathrm{CV}$ is abolished, the trends in these variables run parallel to the ones in states that did not have CV before 1992. Similarly, in our four expenditure variables, for which we do not observe an effect of the elimination of $\mathrm{CV}$, the trends for both types of states run parallel during the whole study period. ${ }^{28}$

\footnotetext{
${ }^{27}$ Ferwerda (2014) uses this federal change in legislation to explore changes in party vote shares; he argues that, given that it was issued at the federal level, it is independent of political dynamics at the local level.

${ }^{28} \mathrm{We}$ also perform a difference-in-difference regression limiting our sample to the parliamentary elections
} 
To further alleviate the concern that CV laws might have been introduced responding to changes in our dependent variables of interest, we include leads and lags of CV in our regressions. If it were the case that CV laws responded to changes in turnout, we would expect turnout in period $t$ to be correlated to either CV in $t+1$ or $\mathrm{CV}$ in $t-1$. The results for our preferred specification in Table A.9 show that, besides the contemporaneous effect of CV on turnout and invalid votes, the introduction of $\mathrm{CV}$ in the previous election or next electoral period has no effect on our variables of interest. The estimated effects for the three types of elections generally show a "zero" of the lags and leads of our independent variable, i.e., there were no pre-trends, or anticipation effects. (One exception is the surprising significance of the coefficient of the lead of CV for presidential elections.)

A potential concern is that authorities anticipate the introduction/repeal of CV laws and alter the level or composition of public spending before the law change takes place. If this were the case, we would observe a correlation between public spending in year $t$ and $\mathrm{CV}$ in $t+1$. Alternatively, any delays in the reaction of public spending to changes in $\mathrm{CV}$ laws would lead to a correlation between $\mathrm{CV}$ in $t-1$ and public spending in year $t$, which would not be captured in our baseline specification. As seen in Table A.10, spending is uncorrelated with CV in the past, current, or future electoral period for all types of elections.

Together, Figure 4 and Tables A.8-A.10 provide evidence supporting the parallel trend assumption, and help rule out potential reverse causation between turnout and CV. As an additional robustness check, in Appendix C, we discuss heterogeneity in our spending (and turnout) results according to levels of turnout in different states.

in the electoral periods between 1986 and 2011. The magnitude and statistical significance of the results is similar to those shown in Tables 3 and 4, suggesting that any other changes in CV (besides the 1992 one) are unlikely to be correlated with trends in the main dependent variables. For further details turn to Table A.8 and Appendix C. 


\section{Understanding the "Null Effect" on Policy Outcomes}

How could it be that CV had sizable impacts on turnout, increasing the number of valid votes, but did not affect policy outcomes? One potential explanation for these results is that the political choices of people who turn out because of CV are, on average, similar to the ones of people who would have voted even in the absence of CV. Another explanation is that median voter preferences may have changed, potentially leading to changes in electoral outcomes, but government spending still does not change for some other reason (e.g., commitment or agency issues). ${ }^{29}$

Besides exploring electoral outcomes, we also attempt to shed light on identifying the voters affected by $\mathrm{CV}$. Several recent studies analyze large increases in turnout due to de jure or de facto enfranchisement of specific groups of the electorate, such as women in Miller (2008); the poor and illiterate in Fujiwara (2015); and African-Americans in Naidu (2012). Unlike these studies, we do not necessarily have a strong prior that people who vote because of CV make significantly different political choices than those who vote even when voting is voluntary.

\section{$5.1 \quad$ Electoral Outcomes}

Table 5 examines whether CV affects various electoral outcomes. We estimate similar regressions as in Section 4.1, but use as dependent variables the percentage of votes to the left or right wing parties, the number of parties, the share of votes of the winning party and its margin of victory (i.e., the difference in vote share between the winning party and the runner-up).

For both parliamentary and state elections, CV does not affect the share of votes going to the

\footnotetext{
${ }^{29}$ For example, in citizen candidate models (Besley and Coate, 1997; Osborne and Silvinski, 1996), politicians may implement preferred policies that may differ from those of the median voter. In empirical work, Lee et al. (2004) (building on the model of Alesina, 1988) show that exogenous changes in party electoral strength do not affect the voting patterns of US congressmen. Another possibility is that uninformed or uninterested voters may have different preferences, but may be less responsive to policy than other voters; in such a scenario, politicians may have little incentive to change their policies.
} 
right or left parties. ${ }^{30}$ Further, there is no response from the political supply: the number of parties remains constant at about 6.9 and 6 for parliamentary and state elections, respectively. Finally, the party that wins the election does not receive a significantly different proportion of votes under CV, compared to states and elections in which voting is voluntary. ${ }^{31}$

In a related paper, Ferwerda (2014) exploits the 1992 constitutional change to analyze the effects of political participation on electoral results. Using municipality level data from 1990 and 1994 (before and after the change), he finds modest impacts the change on electoral outcomes. He finds a slight increase in votes for the left-wing SPÖ, coupled with a slight decrease in votes for minor parties, but his results are broadly similar to ours.

Overall, in Table 5, CV does not significantly affect party vote shares, the number of parties, or margin of victory. Under models with commitment issues, we might have expected CV to affect electoral outcomes, but we do not observe that in the data.

\subsection{Composition of the Electorate}

We use individual data from two rounds of the ASS (1986 and 2003) to examine what type of voters were most affected by CV. The goal is to better understand the mechanisms underlying our main results. We have information on turnout in the previous parliamentary election (1983 and 2002), and exploit within and between state variation in CV introduced by the federal abolition of CV between the surveys (in 1992). While no states had CV in the 2002 parliamentary election, 3 states (Styria, Tyrol, and Vorarlberg) had it in the 1983 elections. Our dependent variable is whether an individual voted in the previous parliamentary election, and our main regressor is a dummy for whether voting was compulsory in that election in the state where the respondent lives. We control for a set of individual covariates, as well as state

\footnotetext{
${ }^{30} \mathrm{We}$ do not perform these regressions for presidential elections because parties do not run as separate entities in those races. Additionally, we find no effects on individual party vote shares or voter polarization. See Appendix C for details. Somewhat relatedly in the literature, Martinez and Gill (2005) examine how turnout affects Democrat vote share in US presidential elections.

${ }^{31}$ Results for the 1979-2010 period shown in Appendix Table A.11 are comparable to those in Table 5. We find relatively larger point estimates for the effects of $\mathrm{CV}$ on party vote shares, but they are not statistically significant. Only for the case of votes for the left wing parties in parliamentary elections do we find a statistically significant impact of CV; however, the effect of CV in this case is small.
} 
and survey year fixed effects. ${ }^{32}$ To examine what type of voters are more likely to respond to $\mathrm{CV}$, we interact $\mathrm{CV}$ with various individual characteristics. ${ }^{33}$

Table 6 shows 8 separate regressions. In the left panel, we observe that impacts of CV seem to be larger among females, those with a vocational middle school degree, and those in the lower two income quartiles. ${ }^{34}$ In this table, the wild bootstrap p-values are larger than the implied p-values from the clustered standard errors, making the inference here more suggestive. In the right panel, we observe that the impact of $\mathrm{CV}$ is larger among people who are not party members, who are not informed (proxied by newspaper reading), who declare themselves uninterested in politics, and who report no party preference. For example, the coefficient of 0.148 in regression 8 indicates that $\mathrm{CV}$ increases turnout by 14.8 percentage points among individuals with no party preference. In contrast, for individuals who declare a party preference toward the main left or right parties in Austria, CV increases turnout by 3-4 percentage points.

Although CV may have affected the gender, educational attainment, and income of the median voter, our results indicate that it may not have shifted the median voter's political preferences. If those induced to vote by $\mathrm{CV}$ do not have strong political views, then such voters may not necessarily vote differently from the median voter in elections without CV. If the choices of the median voter are not shaped by CV (and if party platforms don't change), it would not be surprising if CV failed to affect what party wins and what policies are implemented. These results may also be consistent with a citizen candidate framework in which

\footnotetext{
${ }^{32}$ Controls included in all regressions in this section include: age, age squared, gender, educational attainment, parents' education, working status, household size, community size, party preferences, party membership, interest in politics, and information acquisition (read newspaper regularly).

${ }^{33}$ Although the ASS asks about which party respondents voted for, we do not analyze this outcome because $17 \%$ of our sample did not answer this question, and attrition is differential along individuals' self-reported political preferences.

${ }^{34}$ In regression 1, we examine the impact of $\mathrm{CV}$ on turnout without interaction effects. CV increases turnout by 5.5 percentage points, slightly lower than the effect in the aggregate, state-level data. We must bear in mind, however, that these regressions rely on self-reported data, which might measure turnout with error. A standard concern could be that people might lie about whether they voted. We take comfort from the fact that the self-reported voting shares of $92 \%$ and $82 \%$ in 1983 and 2002 are relatively close to the actual voting shares in our data (93\% and $85 \%$, respectively). The voting shares are not directly comparable across datasets because our administrative turnout measure uses registered voters as the denominator, whereas the survey implicitly uses voting age population as the denominator (see footnote 18), but the general similarity suggests that misrepresentation seems unlikely to be a central issue in the data.
} 
significant changes in the electorate are not necessarily accompanied by changes in policy outcomes. Unfortunately, we do not have enough data to precisely determine which of these two frameworks are more suited to explain the observed results.

\section{External Validity and Conclusion}

Although compulsory voting $(\mathrm{CV})$ is often viewed as a way to foster voter turnout and consequently improve the representativeness of political processes, relatively little is known about how CV causally affects voter participation and, in particular, how it affects economic policy. We analyze these impacts by leveraging quasi-experimental variation in CV laws across Austria's nine states. We find that CV increased turnout from roughly $80 \%$ to $90 \%$. This occurred even though penalties for not voting were rarely enforced. However, in our main results, the increase in turnout did not affect state-level spending (either in levels or shares of sectoral spending) or electoral outcomes. Effects of CV on turnout seem larger among individuals who are uninterested in politics, who do not have strong political views, and who are relatively uninformed (with informedness proxied by newspaper reading). This suggests that individuals swayed to vote by $\mathrm{CV}$ are more likely to exhibit these characteristics (compared to individuals not swayed by CV).

We view our results as consistent with a story where voters swayed to vote by CV do not cast different votes (on average) from those who vote regardless of the law. Our results may also be consistent with other explanations (e.g., citizen candidate models) where politicians implement policies that may not correspond to those preferred by the median voter. Ultimately, it is difficult to say definitively what theoretical mechanism explains our results. Our contribution, though, is to provide causal evidence (previously lacking) that CV laws need not significantly affect government spending. We believe this is important evidence for the policy debate regarding $\mathrm{CV}$.

Overall, our results complement the literature documenting that extension of the voting

franchise to specific population groups impacts policy. Our study suggests that policies aimed 
at increasing turnout (e.g., get-out-the-vote campaigns) need not necessarily affect public spending, and this seems particularly the case if these policies do not increase turnout among voters with specific policy preferences.

Our results are specific to Austria, so it is important to consider to what extent we think the results would extrapolate to other countries. As discussed earlier in Section 3.1, Austria has had relatively high turnout and political involvement even when CV was not in place, at least relative to the US and the OECD averages. At the same time, however, there are a sizable number of countries (e.g., Germany, the Scandinavian countries, and others) that share these features, particularly in Europe. Thus, we believe our findings may be relevant for these countries and other advanced democracies where reforms to increase political participation (such as CV laws) are being evaluated.

How might our results extrapolate for countries with lower levels of political involvement? In terms of turnout, one might imagine that countries with low initial turnout levels might experience even greater turnout increases (in absolute percentage levels) as a result of CV compared to countries like Austria with traditionally high turnout. Thus, our turnout findings could form a "lower bound" for impacts for reforms implemented in countries with low turnout. $^{35}$ Turning to government spending, as observed earlier in the paper, many countries without CV (such as the US) experience significant disparities in turnout along socio-economic lines, which are also correlated with levels of political interest. For Austria, our results suggest that CV induces low-interest or low-knowledge voters to participate. For countries with low initial turnout, while it is possible that voters induced to participate because of CV would have low interest in politics, it is also possible that a broader set of voters would be affected. This might cause CV to actually have a significant impact on government spending. However, as noted by Hodler et al. (2015), changes in voting costs could affect government spending in either direction, and it is challenging to make confident empirical predictions about possible impacts of CV in a setting very different from Austria. Thus, we urge significant caution in

\footnotetext{
${ }^{35}$ However, one can also imagine situations where CV laws have smaller effects on turnout. For example, countries with low turnout may be reflective of citizens being generally distrustful of government and authority. Such characteristics could lead to CV laws having less of an effect on turnout.
} 
assessing the relevance of our results for countries like the US where turnout is much lower than in Austria.

Beyond political involvement, there are a host of other factors that may affect how CV affects government spending including whether there is a presidential or parliamentary system, and whether the population is relatively ethnically heterogeneous or homogenous. While we do not have strong priors on how such factors would influence the impact of CV, we cannot rule out that they may be at play. While our results provide the first quasi-experimental evidence on how CV affects government spending, they are certainly not the last word. We look forward to future research on how CV affects government spending, hopefully using data from additional countries.

\section{References}

Alesina, Alberto, "Credibility and Policy Convergence in a Two-Party System with Rational Voters," American Economic Review, 1988, 78 (4), 796-805.

Bechtel, Michael M., Dominik Hangartner, and Lukas Schmid, "Compulsory Voting, Habit Formation, and Political Participation," 2016. Working Paper.

_ , _, and _ , "Does Compulsory Voting Increase Support for Leftist Policy?," American Journal of Political Science, 2016, 60 (3), 752-767.

Bertrand, Marianne, Esther Duflo, and Sendhil Mullainathan, "How Much Should We Trust Differences-in-Differences Estimates?," Quarterly Journal of Economics, 2004, $119(1), 249-275$.

Besley, Timothy and Stephen Coate, "An Economic Model of Representative Democracy," Quarterly Journal of Economics, 1997, 112 (1), 85-114.

Bischof, Günter and Fritz Plasser, The changing Austrian voter, Vol. 16, Transaction Publishers, 2008. 
Blöndal, Jón R. and Daniel Bergvall, "Budgeting in Austria," OECD Journal on Budgeting, 2007, 7, 1-37.

Börgers, Tilman, "Costly Voting," American Economic Review, 2004, 94 (1), 57-66.

Brady, Henry and John McNulty, "Turning Out the Vote: The Costs of Finding and Getting to the Polling Place," American Political Science Review, 2011, 5 (1), 1-20.

Cameron, A. Colin, Jonah B. Gelbach, and Douglas L. Miller, "Bootstrap-Based Improvements for Inference with Clustered Errors," The Review of Economics and Statistics, May 2008, 90 (3), 414-427.

Cascio, Elizabeth U. and Ebonya Washington, "Valuing the Vote: The Redistribution of Voting Rights and State Funds Following the Voting Rights Act of 1965," The Quarterly Journal of Economics, 2014, 129 (1), 376-433.

Chong, Alberto and Mauricio Olivera, "Does Compulsory Voting Help Equalize Incomes?," Economics and Politics, 2008, 20 (3), 391-415.

Enikolopov, Ruben, Maria Petrova, and Ekaterina Zhuravskaya, "Media and Political Persuasion: Evidence from Russia," American Economic Review, 2010, 111 (7), 3253-3285.

Farber, Henry, "Increasing Voter Turnout: Is Democracy Day the Answer?," 2009. Princeton University Working Paper 546.

Ferwerda, Jeremy, "Electoral Consequences of Declining Participation: A Natural Experiment in Austria," Electoral Studies, 2014, 35, 242-252.

Fowler, Anthony, "Electoral and Political Consequences of Voter Turnout: Evidence from Compulsory Voting in Australia," Quarterly Journal of Political Science, 2013, 8 (2), 159182.

Fraga, Bernard and Eitan Hersh, "Voting Costs and Voter Turnout in Competitive Elections," Quarterly Journal of Political Science, 2010, 5, 339-356. 
Fuentes, Andrew, Eckhard Wurzel, and A. Wörgötter, "Reforming Federal Fiscal Relations in Austria," 2006. OECD Economics Department Working Papers, No. 474, OECD Publishing.

Fujiwara, Thomas, "Voting Technology, Political Responsiveness, and Infant Health: Evidence from Brazil," Econometrica, 2015, 83 (2), 423-464.

Funk, Patricia, "Is there an Expressive Function of Law? An Empirical Analysis of Voting Laws with Symbolic Fines," American Law and Economics Review, 2007, 9 (2), 135-159.

Gallego, Aina, "Unequal Political Participation in Europe," International Journal of Sociology, 2007, $37(4), 10-25$.

Gavazza, Alessandro, Mattia Nardotto, and Tommaso Valletti, "Internet and Politics: Evidence from UK Local Elections and Local Government Policies," 2014.

Gentzkow, Matthew, "Television and Voter Turnout," Quarterly Journal of Economics, 2006, $121(3), 931-972$.

_ , Jesse M. Shapiro, and Michael Sinkinson, "The Effect of Newspaper Entry and Exit on Electoral Politics," American Economic Review, 2011, 101 (7), 931-972.

Gerber, Alan S and Donald P Green, Field experiments: Design, analysis, and interpretation, WW Norton, 2012.

Geys, Benny, "Explaining voter turnout: A review of aggregate-level research," Electoral Studies, 2006, 25, 637-663.

Godefroy, Rafael and Emeric Henry, "Voter turnout, politicians' quality and public expenditures," 2015. Mimeo.

Gomez, Brad, Thomas Hansford, and George Krause, "The Republicans Should Pray for Rain: Weather, Turnout, and Voting in U.S. Presidential Elections," Journal of Politics, 2007, 69, 649-663. 
Gradstein, Mark and Branko Milanovic, "Does Liberté = Egalité? A Survey of the Empirical Links between Democracy and Inequality with Some Evidence on the Transition Economies," Journal of Economic Surveys, 2004, 18 (4), 515-537.

Haller, Max, Kurt Holm, and R. Oldenbourg Verlag, Werthaltungen und Lebensformen in Österreich. Ergebnisse des Sozialen Survey 1986, Munich: R. Oldenbourg Verlag, 1987.

_, Wolfgang Schulz, and Alfred Grausgruber, Österreich zur Jahrhundertwende. Gesellschaftliche Werthaltungen und Lebensqualität 1986-2004, Wiesbaden: Verlag für Sozialwissenschaften, 2005.

Hansford, Thomas and Brad Gomez, "Estimating the Electoral Effects of Voter Turnout," American Political Science Review, 2010, 104 (2), 268-288.

Herrera, Helios, Massimo Morelli, and Thomas Palfrey, "Turnout and power sharing," The Economic Journal, 2014, 124 (574), F131-F162.

Hinnerich, Björn Tyrefors and Per Pettersson-Lidbom, "Democracy, Redistribution, and Political Participation: Evidence From Sweden 1919-1938," Econometrica, 2014, 82 (3), 961-993.

Hirczy, Wolfgang, "The Impact of Mandatory Voting Laws on Turnout: A QuasiExperimental Approach," Electoral Studies, 1994, 13 (1), 64-76.

Hodler, Roland, Simon Luechinger, and Alois Stutzer, "The Effects of Voting Costs on the Democratic Process and Public Finances," American Economic Journal: Economic Policy, 2015, 7 (1), 141-171.

Husted, Thomas A. and Lawrence W. Kenny, "The Effect of the Expansion of the Voting Franchise on the Size of Government," Journal of Political Economy, 1997, 105, $54-82$. 
IMF, "Austria: Selected Issues," 2008. International Monetary Fund Country Report No. $08 / 189$.

Knack, Steve, "Does Rain Help Republicans? Theory and Evidence on Turnout and Vote," Public Choice, 1994, 79, 187-209.

Krasa, Stefan and Matthias K. Polborn, "Is mandatory voting better than voluntary voting?," Games and Economic Behavior, 2009, 66 (1), 275-291.

Krishna, Vijay and John Morgan, "Overcoming Ideological Bias in Elections," Journal of Political Economy, 2011, 119 (2), 183-211.

Kritzinger, Sylvia, Eva Zeglovits, Michael S Lewis-Beck, and Richard Nadeau, The Austrian Voter, Vandenhoeck \& Ruprecht, 2013.

Lee, David S., Enrico Moretti, and Matthew J. Butler, "Do Voters Affect Or Elect Policies? Evidence from the U. S. House," Quarterly Journal of Economics, 2004, 119 (3), $807-859$.

Lehner, Gerhard, Die Bundesländer im Finanzausgleich, WIFO: Austrian Institute for Economic Research, 1997.

Leon, Fernanda Leite Lopez De and Renatai Rizzi, "A Test for the Rational Ignorance Hypothesis: Evidence from a Natural Experiment in Brazil," American Economic Journal: Economic Policy, 2014, 6 (4), 380-398.

León, Gianmarco, "Turnout, Political Preferences and Information: Experimental Evidence from Peru," 2015. BREAD Working Paper 376.

Lijphart, Arend, "Unequal Participation: Democracy's Unresolved Dilemma," American Political Science Review, 1997, 91 (1), 1-14.

Linz, Juan, Alfred Stephan, and Yogendra Yadav, Democracy and Diversity, New Delhi: Oxford University Press, 2007. 
Mahler, Vincent A, David K Jesuit, and Piotr R Paradowski, "Electoral Turnout and State Redistribution A Cross-National Study of Fourteen Developed Countries," Political Research Quarterly, 2014, 67 (2), 361-373.

Martinez, Michael D and Jeff Gill, "The effects of turnout on partisan outcomes in US presidential elections 1960-2000," Journal of Politics, 2005, 67 (4), 1248-1274.

Meltzer, Allan H. and Scott F. Richard, "A Rational Theory of the Size of Government," Journal of Political Economy, 1981, 89 (5), 914-927.

Miller, Grant, "Women's Sufrage, Political Responsiveness, and Child Survival in American History," The Quarterly Journal of Economics, 2008, 123 (3), 1287-1327.

Naidu, Suresh, "Suffrage, Schooling, and Sorting in the Post-Bellum U.S. South," 2012. NBER Working Paper18129.

OECD, "Managing across Levels of Government: Austria," 1997, pp. 93-106.

Osborne, Martin J. and Al Silvinski, "A Model of Political Competition with CitizenCandidates," The Quarterly Journal of Economics, 1996, 111 (01), 65-96.

Persson, Torsten and Guido Tabellini, Political Economics: Explaining Economic Policy, Cambridge MA: MIT Press, 2000.

Powell Jr, G Bingham, "American voter turnout in comparative perspective," The American Political Science Review, 1986, pp. 17-43.

Rodriguez, F. C, "Does Distributional Skewness Lead to Redistribution? Evidence from the United States," Economics and Politics, 1999, 11, 171-199.

Shineman, Victoria, "Isolating the Effect of Compulsory Voting Laws on Political Sophistication: Exploiting Intra-National Variation in Mandatory Voting Laws Between the Austrian Provinces," 2014. 
Stromberg, David, "Radio's Impact on Public Spending," Quarterly Journal of Economics, 2004, $119(1), 589-621$.

Timpone, Richard J., "Structure, Behavior, and Voter Turnout in the United States," The American Political Science Review, 1998, 92 (1), 145-158.

_, "Demokratische Beteiligung und Staatsausgaben: Die Auswirkungen des Frauenstimmrechts," Swiss Journal of Economics and Statistics, 2005, 141 (4), 617-650.

Washington, Ebonya, "How Black Candidates Affect Voter Turnout," Quarterly Journal of Economics, 2006, 121 (3), 979-998. 


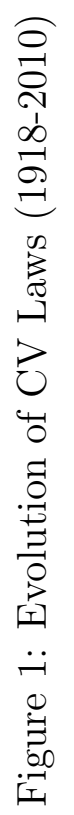

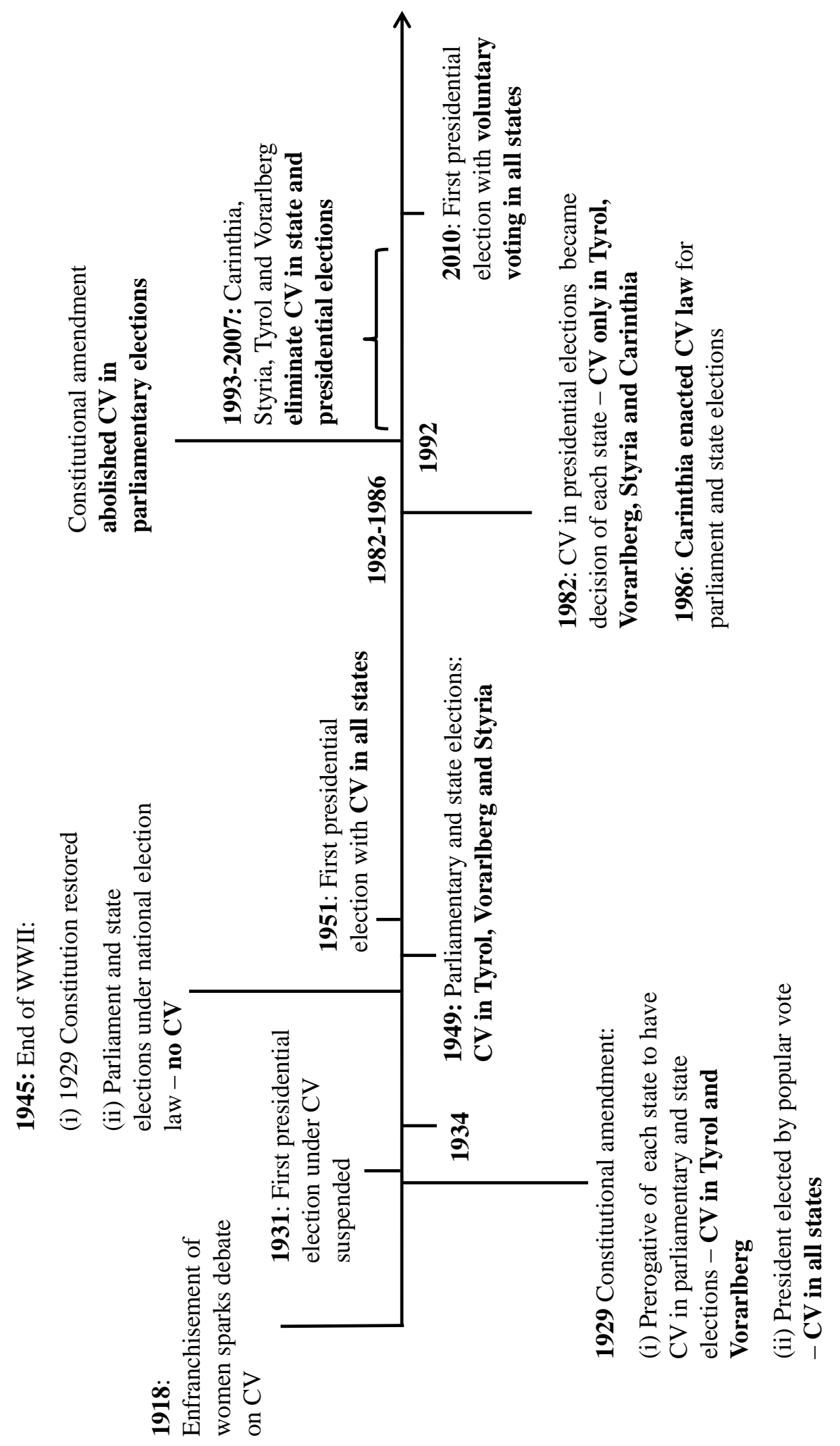




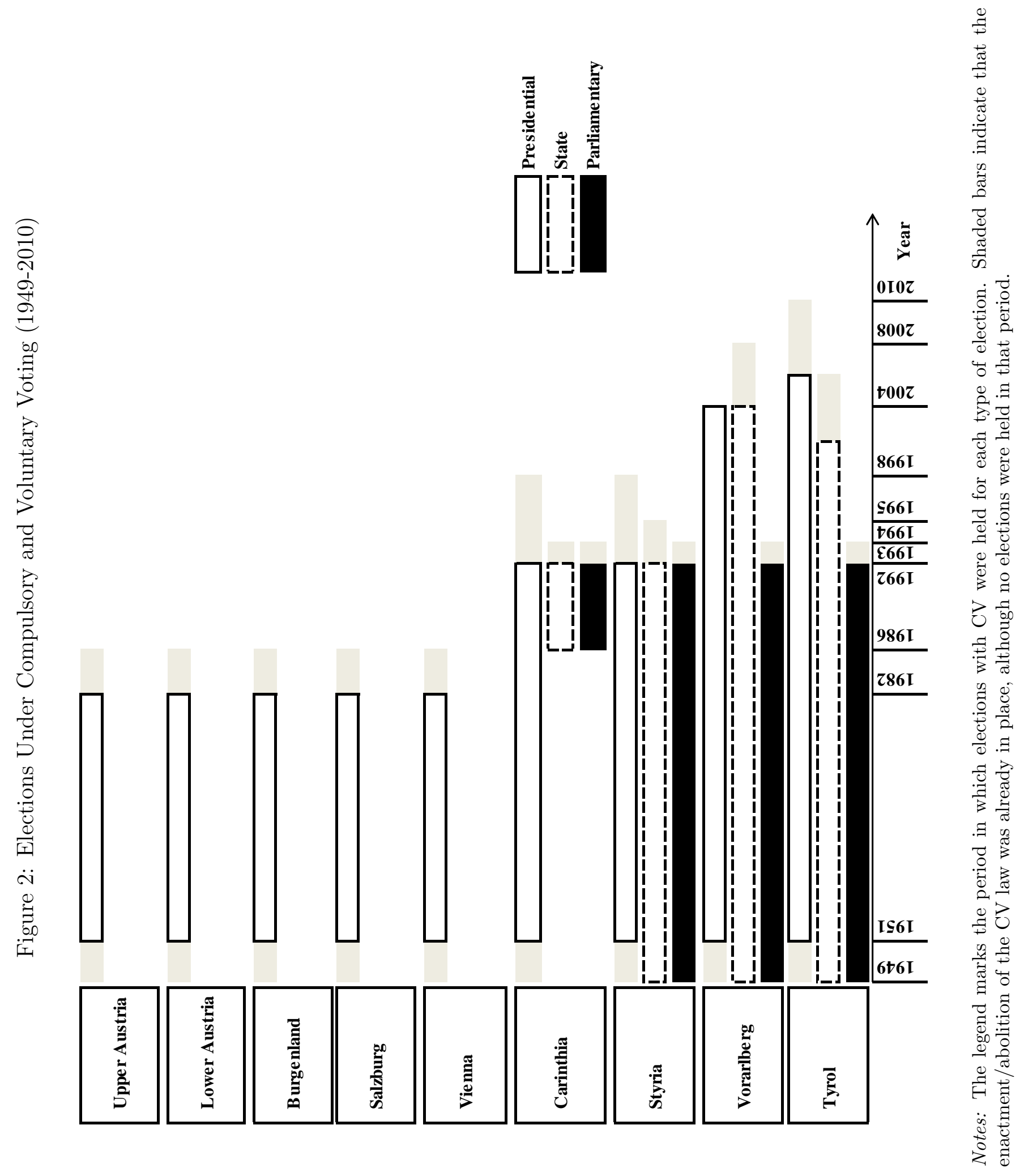




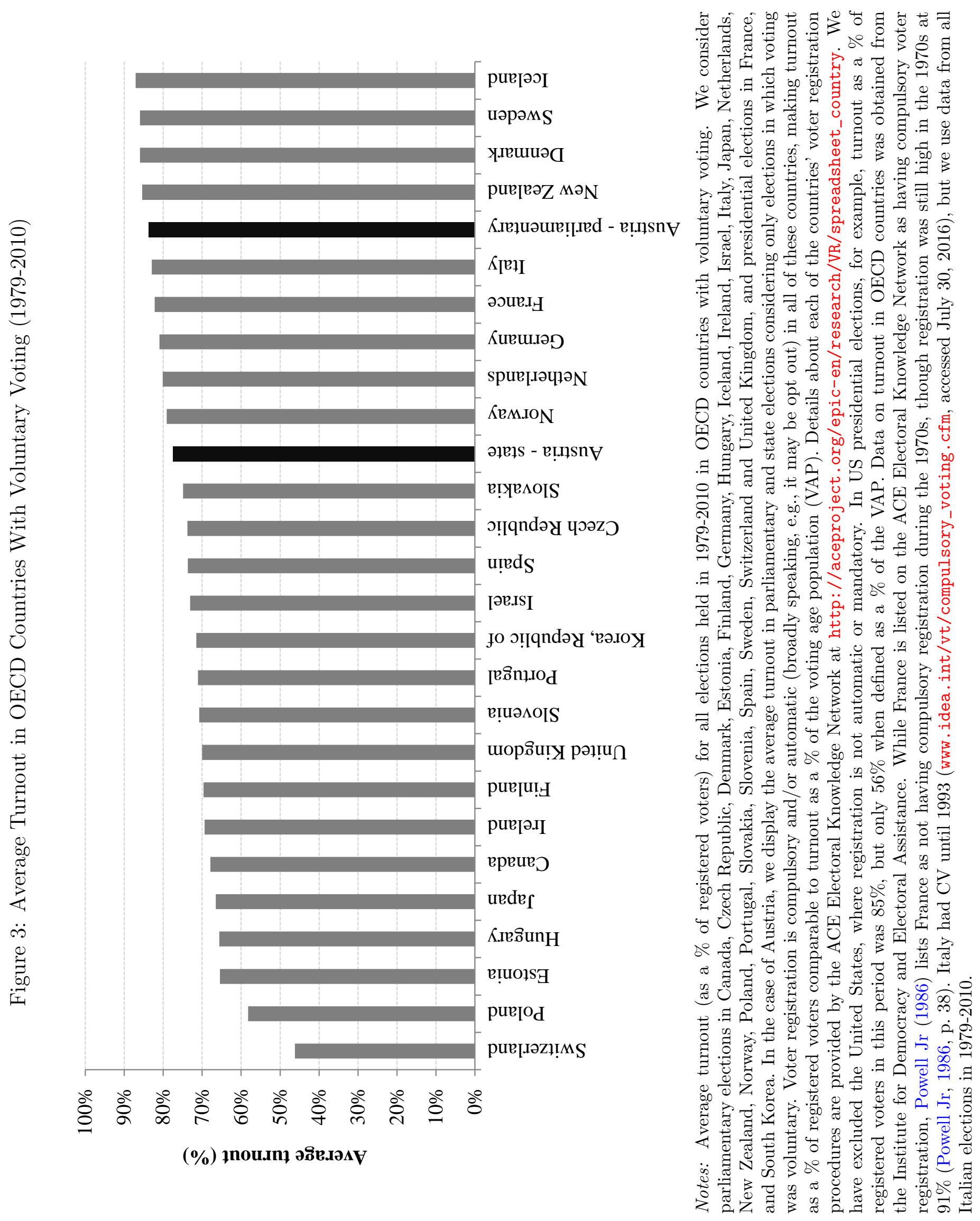




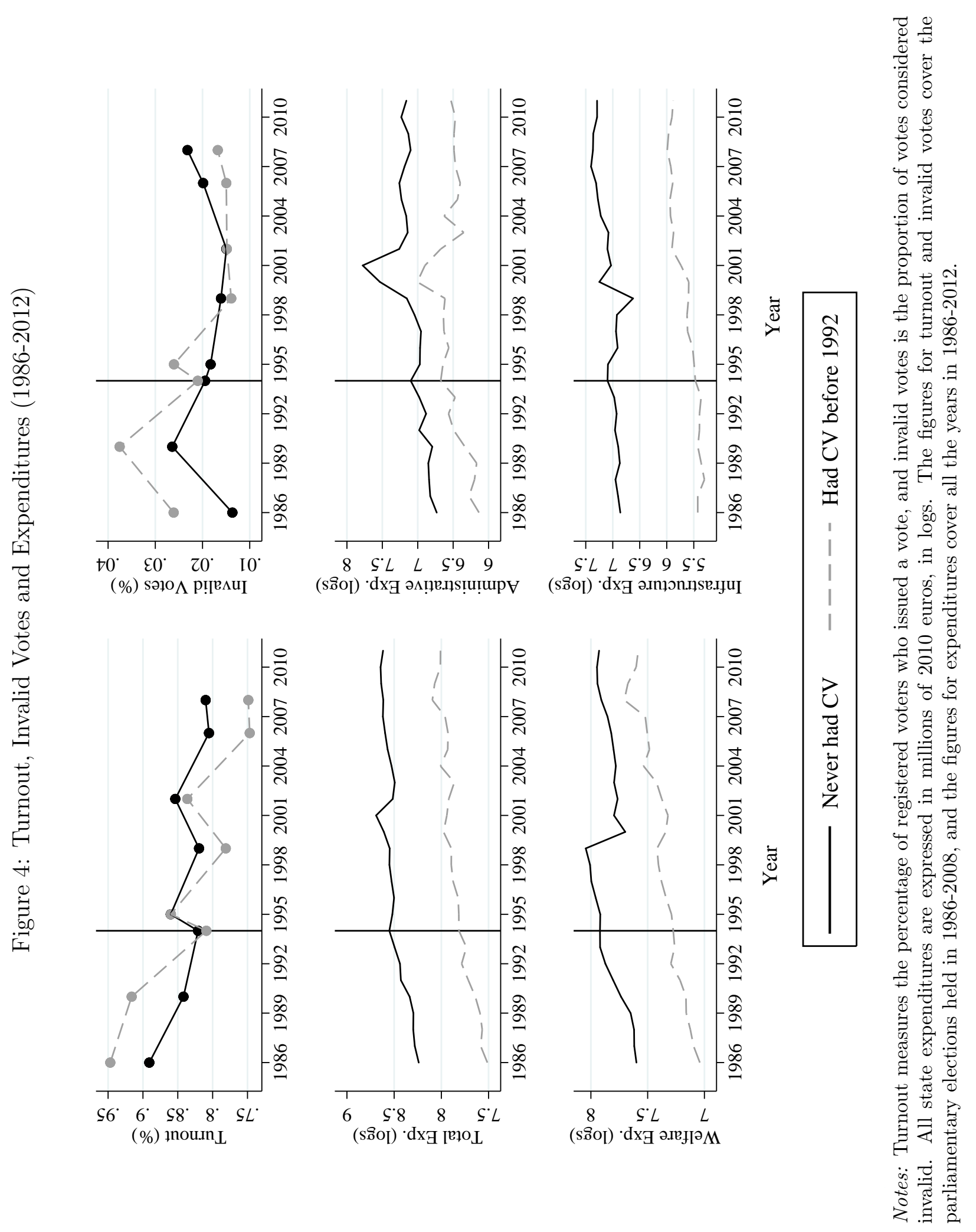


Table 1: Summary Statistics (1949-2012)

\begin{tabular}{|c|c|c|c|c|c|}
\hline & Observations & Mean & Std. Dev & Min & Max \\
\hline \multicolumn{6}{|c|}{ Panel A: Election Data (1949-2010) } \\
\hline \multicolumn{6}{|l|}{ Parliamentary Elections } \\
\hline Turnout (\%) & 171 & 0.90 & 0.07 & 0.70 & 0.98 \\
\hline Invalid Votes(\%) & 171 & 0.02 & 0.01 & 0.01 & 0.05 \\
\hline Votes Right (\%) & 171 & 0.52 & 0.09 & 0.22 & 0.75 \\
\hline Votes Left (\%) & 171 & 0.40 & 0.10 & 0.15 & 0.62 \\
\hline Votes Minor Parties (\%) & 171 & 0.09 & 0.09 & 0.00 & 0.49 \\
\hline Number of Parties & 171 & 6.96 & 2.94 & 4.00 & 13.00 \\
\hline Vote Share Winner (\%) & 171 & 0.47 & 0.08 & 0.29 & 0.65 \\
\hline Margin of Victory (\%) & 171 & 0.12 & 0.09 & 0.00 & 0.40 \\
\hline \multicolumn{6}{|l|}{ State Elections } \\
\hline Turnout (\%) & 121 & 0.86 & 0.09 & 0.61 & 0.98 \\
\hline Invalid Votes(\%) & 121 & 0.02 & 0.01 & 0.01 & 0.08 \\
\hline Votes Right (\%) & 121 & 0.53 & 0.11 & 0.21 & 0.76 \\
\hline Votes Left (\%) & 121 & 0.39 & 0.11 & 0.10 & 0.62 \\
\hline Votes Minor Parties (\%) & 121 & 0.07 & 0.08 & 0.00 & 0.50 \\
\hline Number of Parties & 121 & 5.98 & 1.05 & 4.00 & 8.00 \\
\hline Vote Share Winner (\%) & 121 & 0.49 & 0.06 & 0.36 & 0.65 \\
\hline Margin of Victory (\%) & 121 & 0.10 & 0.07 & 0.00 & 0.34 \\
\hline \multicolumn{6}{|l|}{ Presidential Elections } \\
\hline Turnout (\%) & 132 & 0.88 & 0.13 & 0.38 & 1.00 \\
\hline Invalid Votes(\%) & 135 & 0.04 & 0.02 & 0.01 & 0.11 \\
\hline \multicolumn{6}{|c|}{ Panel B: Yearly State Data (1980-2012) } \\
\hline Unemployment Rate (\%) & 297 & 0.06 & 0.02 & 0.00 & 0.10 \\
\hline Population (in thousands) & 297 & 890 & 492 & 269 & 1717 \\
\hline Administrative Expenditures & 297 & 898.67 & 779.60 & 118.98 & 4303.17 \\
\hline Representatives and gen. admin & 297 & 423.67 & 431.13 & 74.81 & 2280.97 \\
\hline Finance & 297 & 475.00 & 485.26 & 42.20 & 3699.91 \\
\hline Welfare Expenditures & 297 & 1977.86 & 1415.89 & 341.19 & 6916.49 \\
\hline Education, sports and science & 297 & 636.42 & 399.04 & 138.80 & 1774.97 \\
\hline Social welfare and housing & 297 & 701.01 & 521.13 & 106.37 & 2315.46 \\
\hline Health & 297 & 569.51 & 548.88 & 81.82 & 2977.10 \\
\hline Arts, culture and religion & 297 & 70.92 & 62.89 & 9.91 & 288.36 \\
\hline Infrastructure Expenditures & 297 & 763.11 & 1141.22 & 72.16 & 4818.05 \\
\hline Roads and transport & 297 & 230.64 & 211.70 & 47.55 & 1010.88 \\
\hline Public order and security & 297 & 26.03 & 39.55 & 1.21 & 163.66 \\
\hline Promotion of the economy & 297 & 121.33 & 64.87 & 21.13 & 318.33 \\
\hline Services & 297 & 385.11 & 933.29 & 0.98 & 4055.52 \\
\hline
\end{tabular}

Notes: State-level election data covers all elections held from 1949 to 2010. Turnout measures the percentage of registered voters who issued a vote, and invalid votes is the proportion of ballots considered invalid. Vote shares for the right and left are the percentage of valid votes that went to ÖVP + FPÖ and SPÖ + KPÖ, respectively. Votes shares for minor parties are the percentage of valid votes received by other smaller parties. The vote share of the winner is the percentage of valid votes obtained by the highest ranking party in each state, and margin of victory is the difference in vote shares between the highest ranking party and the runnerup. Expenditure, unemployment, and population data at the state-level cover all the years from 1980 to 2012. All state expenditures are expressed in millions of 2010 euros. 
Table 2: Descriptive Statistics: 1986 and 2003 Austrian Social Survey

\begin{tabular}{|c|c|c|c|c|c|}
\hline & Observations & Mean & Std. Dev & Min & $\operatorname{Max}$ \\
\hline \multicolumn{6}{|l|}{ Turnout } \\
\hline Voted in Last Parliamentary Elections (\%) & 3726 & 0.87 & 0.34 & 0.00 & 1.00 \\
\hline \multicolumn{6}{|l|}{ Political Party of Preference } \\
\hline $\begin{array}{l}\text { Left }(\%) \\
\text { Right }(\%) \\
\text { Minor Parties }(\%) \\
\text { No Party Preference }(\%) \\
\text { Not member of a Political Party }(\%)\end{array}$ & $\begin{array}{l}3670 \\
3670 \\
3670 \\
3670 \\
3693\end{array}$ & $\begin{array}{l}0.29 \\
0.34 \\
0.07 \\
0.30 \\
0.82\end{array}$ & $\begin{array}{l}0.45 \\
0.47 \\
0.25 \\
0.46 \\
0.39\end{array}$ & $\begin{array}{l}0.00 \\
0.00 \\
0.00 \\
0.00 \\
0.00\end{array}$ & $\begin{array}{l}1.00 \\
1.00 \\
1.00 \\
1.00 \\
1.00\end{array}$ \\
\hline \multicolumn{6}{|l|}{ Interest in Politics and Information } \\
\hline $\begin{array}{l}\text { Uninterested in Politics (\%) } \\
\text { Mildly Interested in Politics(\%) } \\
\text { Very Interested in Politics (\%) } \\
\text { Does not read newspaper regularly }\end{array}$ & $\begin{array}{l}3723 \\
3723 \\
3723 \\
3705\end{array}$ & $\begin{array}{l}0.36 \\
0.40 \\
0.24 \\
0.31\end{array}$ & $\begin{array}{l}0.48 \\
0.49 \\
0.43 \\
0.46\end{array}$ & $\begin{array}{l}0.00 \\
0.00 \\
0.00 \\
0.00\end{array}$ & $\begin{array}{l}1.00 \\
1.00 \\
1.00 \\
1.00\end{array}$ \\
\hline \multicolumn{6}{|l|}{ Socioeconomic Variables } \\
\hline $\begin{array}{l}\text { Age } \\
\text { Female } \\
\text { Household Income (in } 2003 \text { Euros) } \\
\text { Number of members in household } \\
\text { Employed (\%) } \\
\text { Unemployed (\%) } \\
\text { Retired (\%) }\end{array}$ & $\begin{array}{l}3726 \\
3726 \\
2918 \\
3726 \\
3726 \\
3726 \\
3726\end{array}$ & $\begin{array}{c}46.04 \\
0.59 \\
1797.95 \\
2.85 \\
0.49 \\
0.03 \\
0.27\end{array}$ & $\begin{array}{c}16.71 \\
0.49 \\
963.54 \\
1.57 \\
0.50 \\
0.17 \\
0.44\end{array}$ & $\begin{array}{c}18.00 \\
0.00 \\
180.00 \\
1.00 \\
0.00 \\
0.00 \\
0.00\end{array}$ & $\begin{array}{c}92.00 \\
1.00 \\
4341.90 \\
9.00 \\
1.00 \\
1.00 \\
1.00\end{array}$ \\
\hline \multicolumn{6}{|l|}{ Educational Attainment } \\
\hline $\begin{array}{l}\text { Compulsory Schooling (\%) } \\
\text { Vocational Middle School (\%) } \\
\text { High School (\%) } \\
\text { College }(\%)\end{array}$ & $\begin{array}{l}3726 \\
3726 \\
3726 \\
3726\end{array}$ & $\begin{array}{l}0.65 \\
0.13 \\
0.16 \\
0.06\end{array}$ & $\begin{array}{l}0.48 \\
0.34 \\
0.37 \\
0.24\end{array}$ & $\begin{array}{l}0.00 \\
0.00 \\
0.00 \\
0.00\end{array}$ & $\begin{array}{l}1.00 \\
1.00 \\
1.00 \\
1.00\end{array}$ \\
\hline
\end{tabular}

Notes: The sample includes all individuals in the 1986 and 2003 Austrian Social Survey who reported whether they voted in the last parliamentary elections (1983 and 2002) and were of voting age. Political party of preference specifies the party the respondent identifies with (left if SPÖ or KPÖ, right if ÖVP or FPÖ, no party preference if the individual does not identify with any party, and minor parties otherwise), and not a member of a political party is a dummy for whether the individual has no party affiliation. Individuals are separated into three categories according to whether they manifest to be uninterested, mildly or very interested in politics. The Austrian Social Survey separates household income into 21 different categories. To make the figures comparable across periods, we imputed household income as the midpoint of the category into which individuals fell, and converted the 1986 mid-point into 2003 euros. Educational variables are mutually exclusive dummies for the maximum educational attainment. The educational category of "Vocational Middle School" corresponds with "berufsbildende mittlere Schule" (or "bms") in the data. 


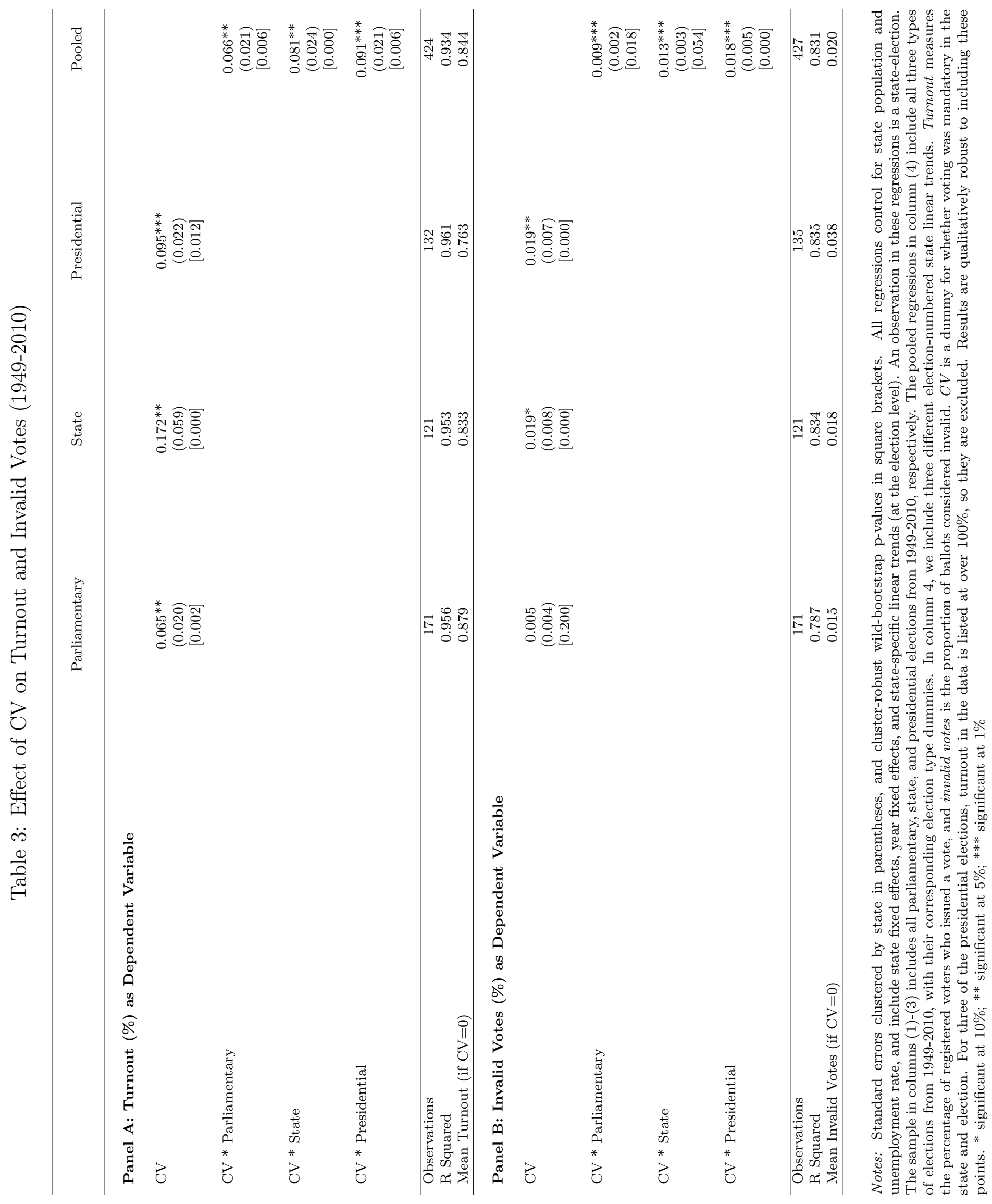




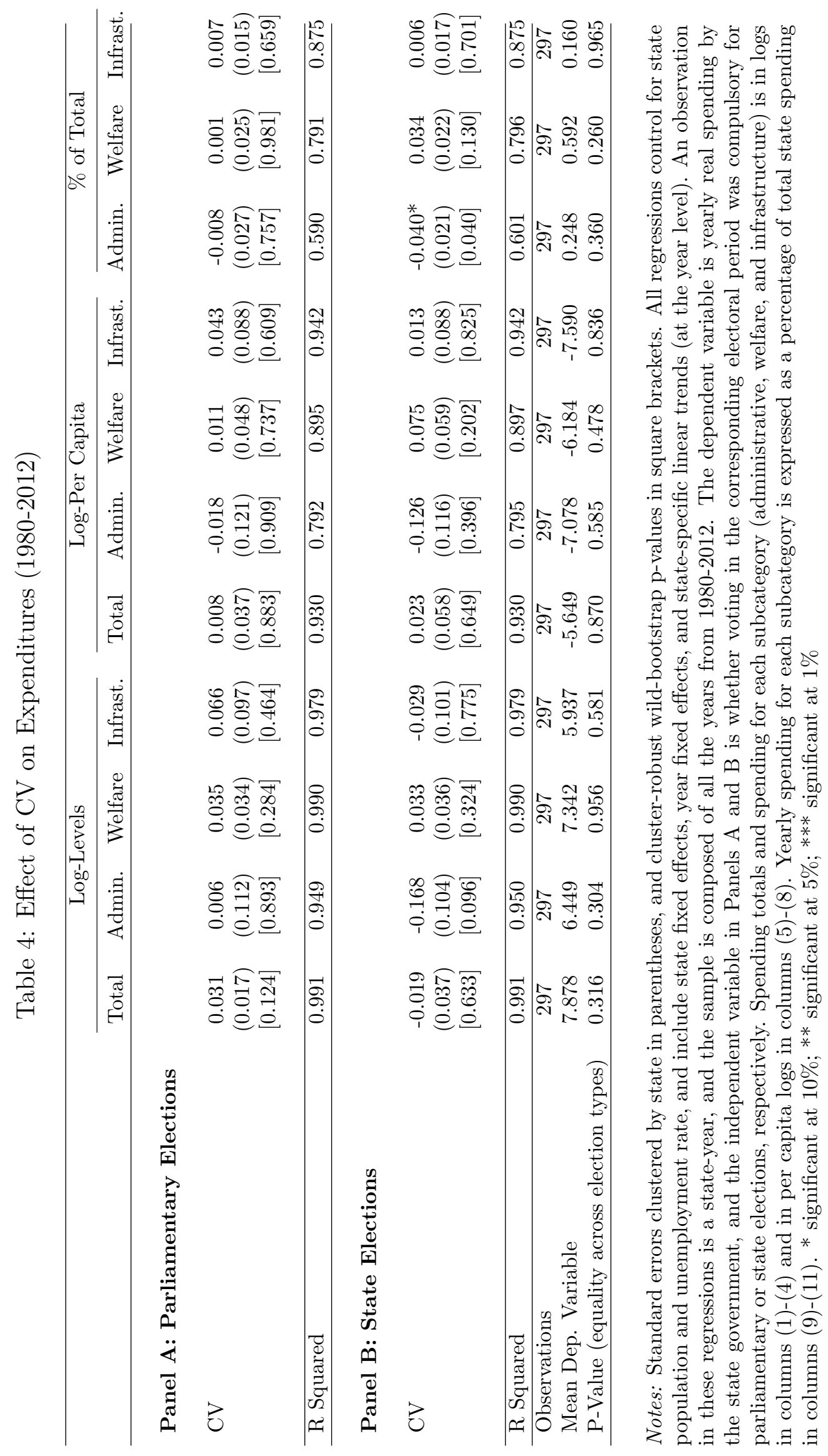




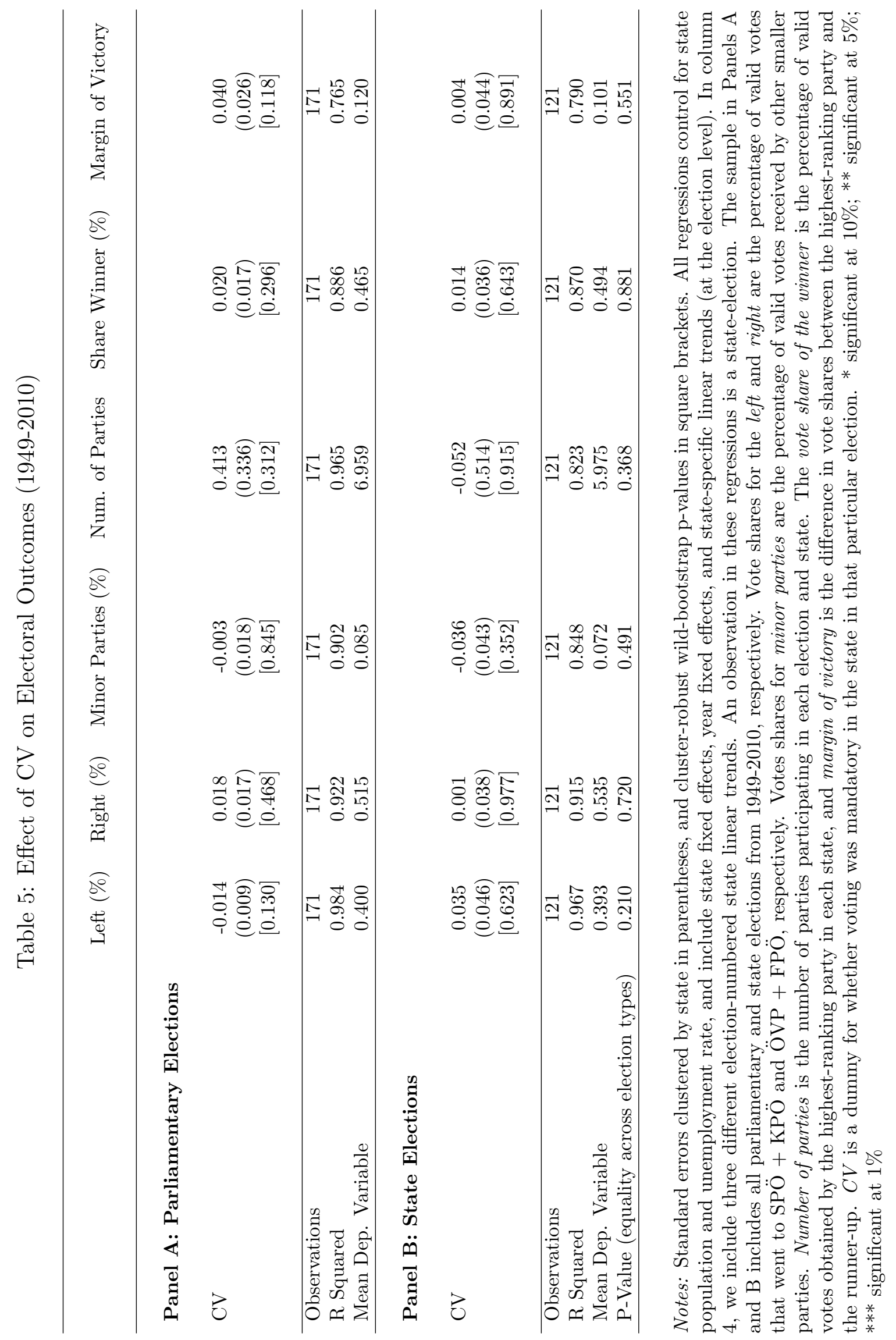




\section{Table 6: Individual-level Impact of CV on Turnout: Heterogeneity by Voter Characteristics}

Dependent Variable: Voted in Last Parliamentary Elections

1) Effect of CV on Turnout

CV

\section{2) Gender}

Female $^{*} \mathrm{CV}$

Male * CV

\section{3) Educational Attainment}

Compulsory Schooling * CV

Vocational Middle School * CV

High School or College * CV

\section{4) Income Quartile}

Income Q1 * CV

Income Q2 * CV

Income Q3 * CV

Income $\mathrm{Q} 4 * \mathrm{CV}$
$0.055^{*}$

$(0.028)$

[0.209]

Party Member * CV

5) Party Membership

Not Party Member * CV

$0.066^{*}$

$(0.029)$

$[0.235]$

0.011

$(0.028)$

$[0.768]$

6) Informed. vs Uninformed Citizens

$0.087^{* *}$

$(0.033)$

[0.311]

Informed $* \mathrm{CV}$

0.043

$(0.027)$

$[0.225]$

7) Interest in Politics

Uninterested * CV

$0.082^{*}$

$(0.039)$

[0.253]

Mildly Interested ${ }^{*} \mathrm{CV}$

0.045

$(0.024)$

[0.161]

Very Interested * CV

0.017

$(0.029)$

[0.576]

8) Self-Reported Political Preference

Left $* \mathrm{CV}$

0.039

$0.072^{*}$

(0.034)

[0.217]

$0.075 *$

(0.039)

[0.271]

Right $* \mathrm{CV}$

[0.271]

0.034

(0.022)

[0.245]

0.029

(0.034)

[0.467]

Minor Parties * CV

$-0.017$

(0.153)

[0.928]

No Party Preference * CV

Notes: This table presents 8 separate regressions numbered 1-8. Except for regression 1, the coefficients shown are interactions of $C V$ with individual characteristics. In regression 6 , we use whether someone regularly reads the newspaper as a proxy for whether they are informed. Standard errors clustered by state in parentheses, and cluster-robust wild-bootstrap p-values in square brackets. The dependent variable in all regressions is a dummy for whether the individual voted in the previous parliamentary elections. $C V$ is a dummy for whether voting was compulsory for that election in the individual's state of residence. All regressions include baseline controls for age, age squared, gender, educational attainment, parents' education, working status, household size, community size, self-reported political preference, party membership, being informed, interest in politics, state fixed effects, and survey year fixed effects. Regression 4 includes income quartile controls (excluded from the other regressions because they sometimes have missing data). The sample includes all individuals in the 1986 and 2003 Austrian Social Survey who reported whether they voted in the last parliamentary elections (1983 and 2002) and were of voting age. Regression 4 has 2,647 observations, whereas all other regressions have 3,369 observations. $*$ significant at $10 \% ; * *$ significant at $5 \% ; * *$ significant at $1 \%$ 


\section{Online Appendix for "Compulsory Voting, Turnout, and Government Spending: Evidence from Austria"}

Mitchell Hoffman, Gianmarco León, and María Lombardi

The Online Appendix is organized as follows. Appendix A provides additional figures and tables. Appendix B provides additional institutional background details on compulsory voting in Austria. Appendix C provides additional discussion and results.

\section{Appendix A Appendix Tables}




\section{Administrative Expenses}

i) Elected representatives and general administration:

State parliament, state government, state government delegations, sub-state governments, special offices, committees, pensions, personnel expenses, and other tasks of the public administration.

\section{ii) Finance:}

Capital assets and unincorporated foundations, financial allocations and grants, liabilities, budgetary compensation, and handover and takeover of the annual results.

\section{Welfare Expenses}

i) Education, sports and science:

Secondary education, vocational education and teacher formation, preschool education, education promotion, extracurricular educational activities for the youth, sports and extracurricular physical education, adult educa-

tion, and research and science.

\section{ii) Social welfare and promotion of house construction:}

General public welfare, youth welfare, emergency funds, social and family policies, and housing subsidies.

\section{iii) Health:}

Health services, environmental protection, rescue and warning services, health worker training, public hospitals, hospitals operated by other legal entities, and veterinary medicine.

iv) Arts, culture and religion:

Fine arts, music and performing arts, literature and language, museums, heritage preservation, radio, press, films, and church affairs.

\section{Infrastructure Expenses}

i) Road construction, hydraulic engineering and transport:

Road construction and maintenance, hydraulic construction, flood protection, road/rail/water traffic, aviation, and postal and telecommunication services.

\section{ii) Promotion of the economy:}

Improvement and promotion of agriculture and forestry, promotion of energy, tourism, trade, commerce, and industry.

\section{iii) Services:}

Public services (water supply, lighting, waste management, etc.), residential and commercial buildings, and utility companies.

\section{iv) Public order and security:}

Public order, security and special police, firefighting, disaster relief and national defense.

Notes: Detailed breakdown of each category was obtained from Appendix 2 of the 787/1996 Ministry of Finance regulation on budgeting and accounts (Voranschlags- und Rechnungsabschluverordnung VRV). 


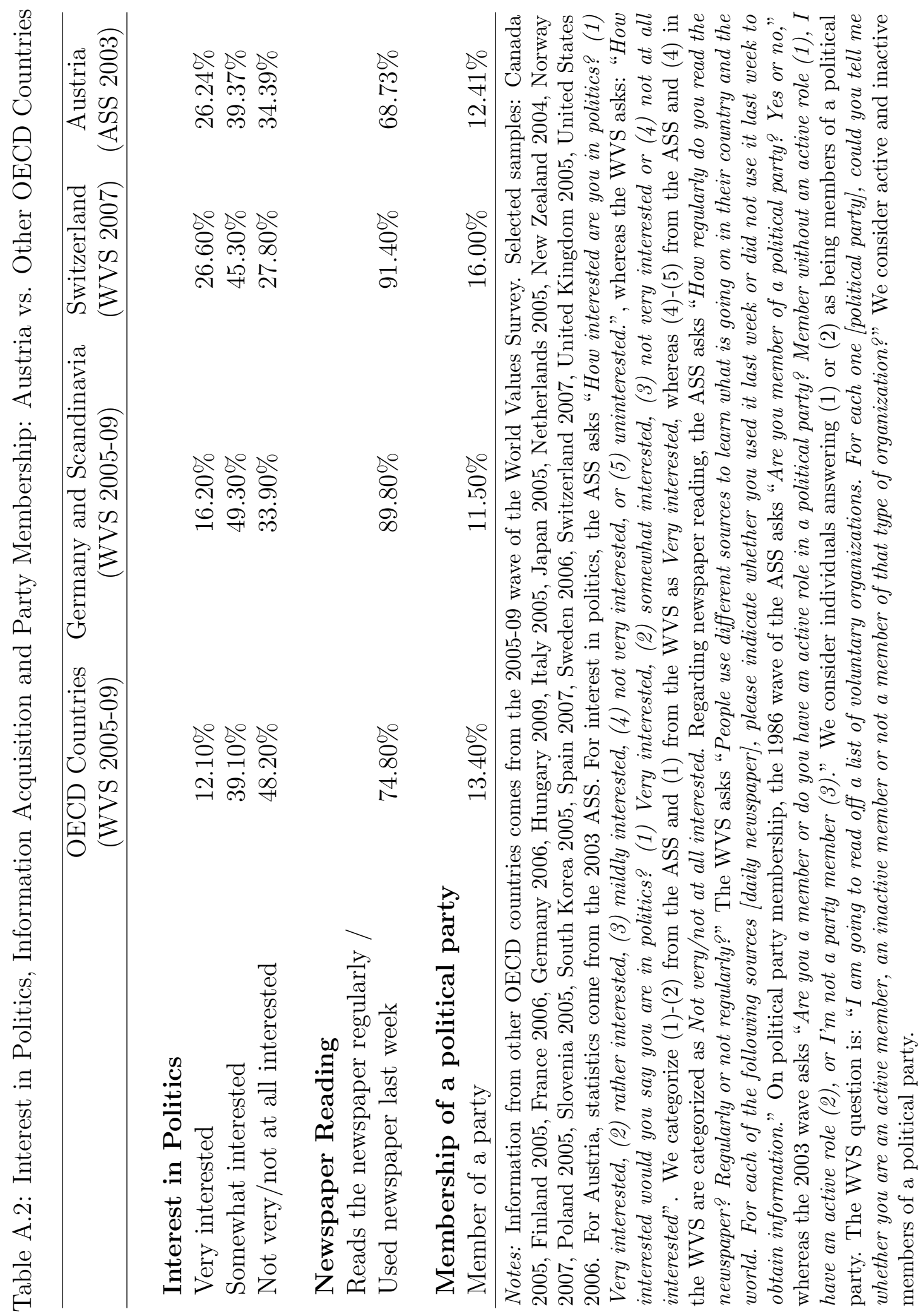




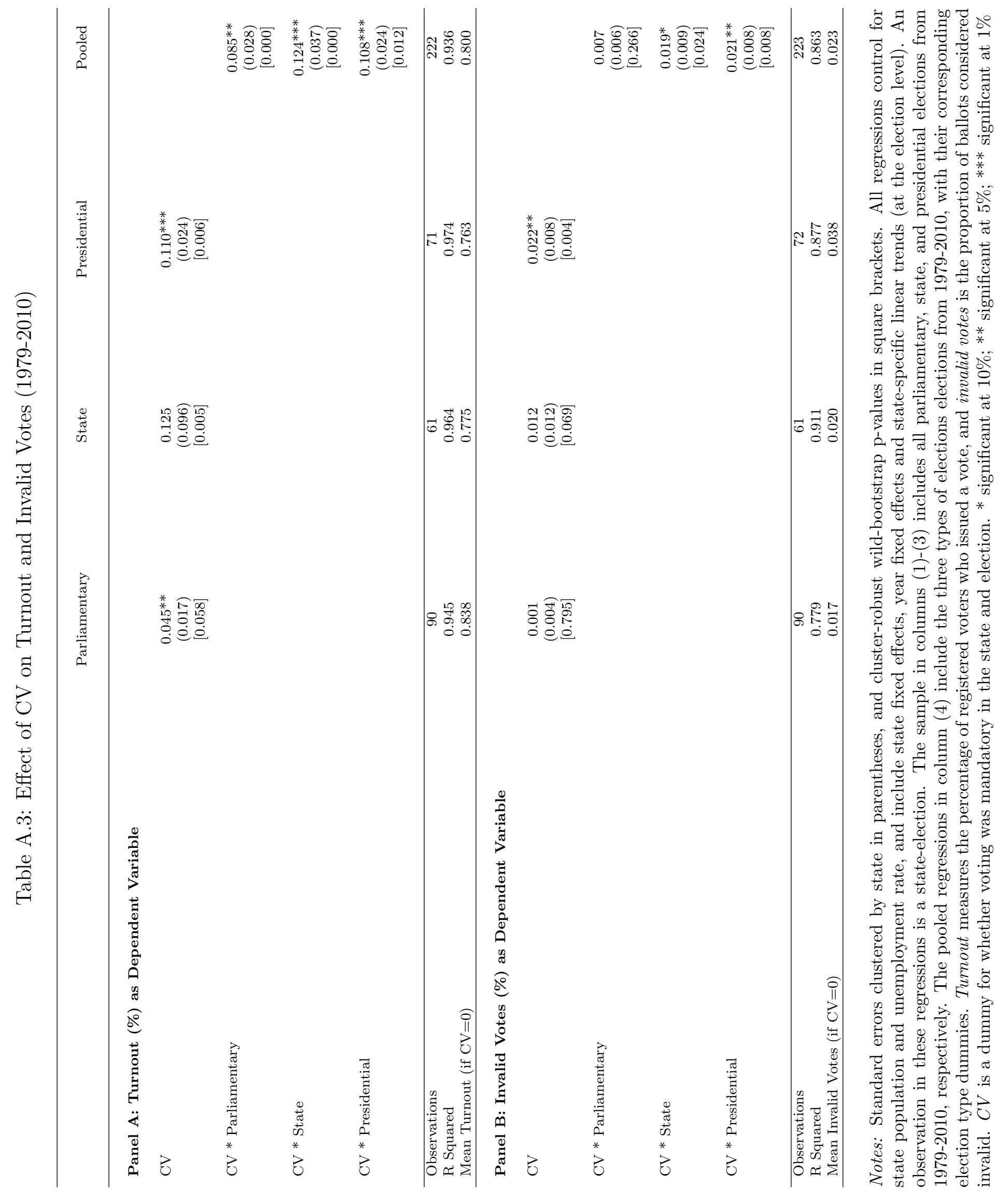




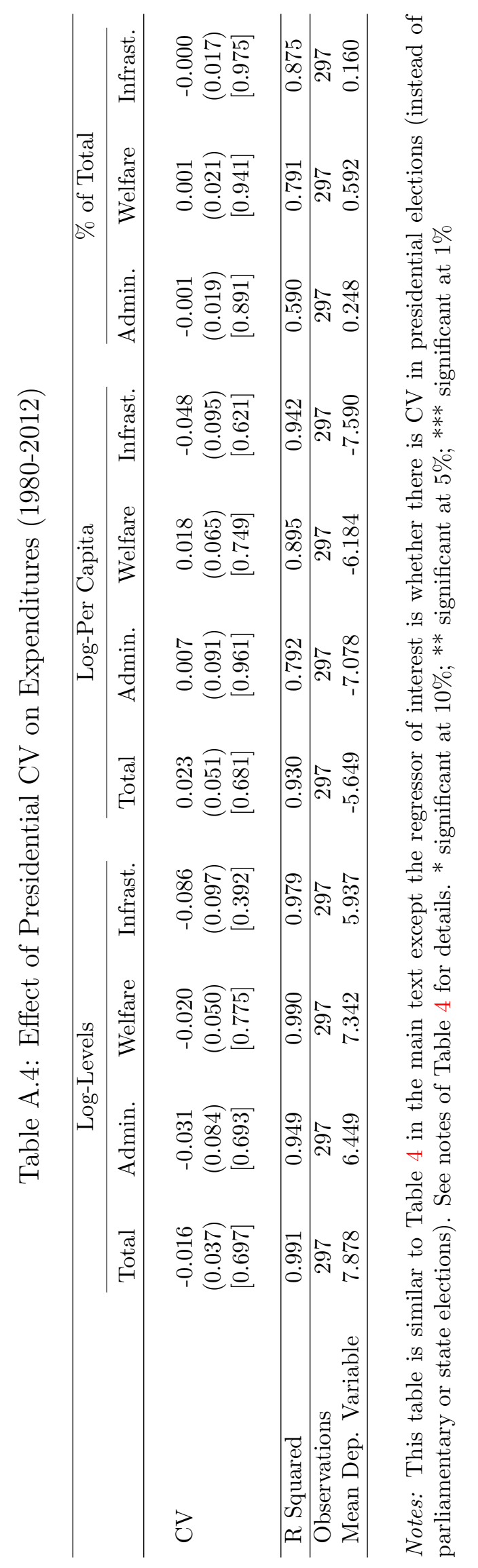




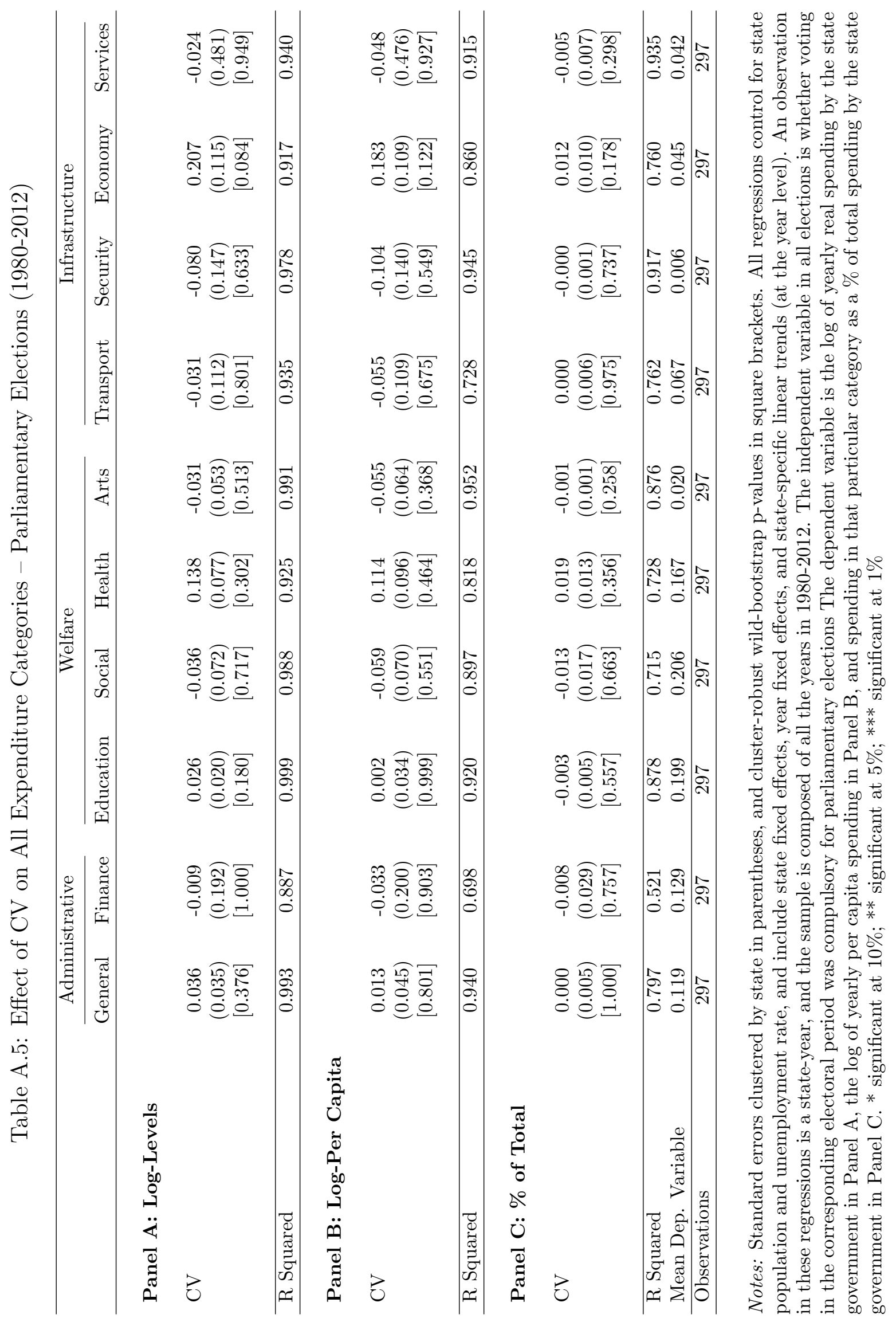




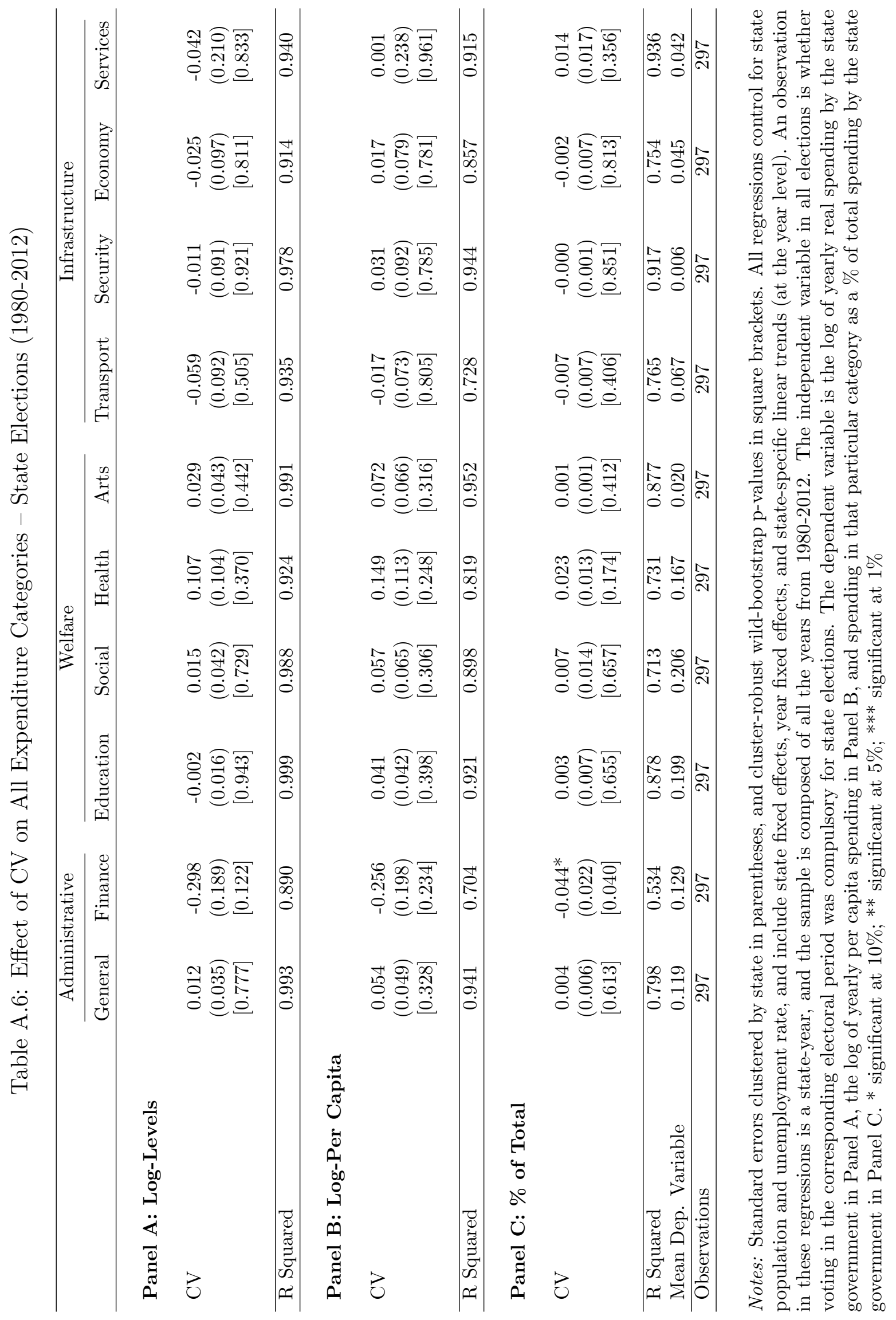




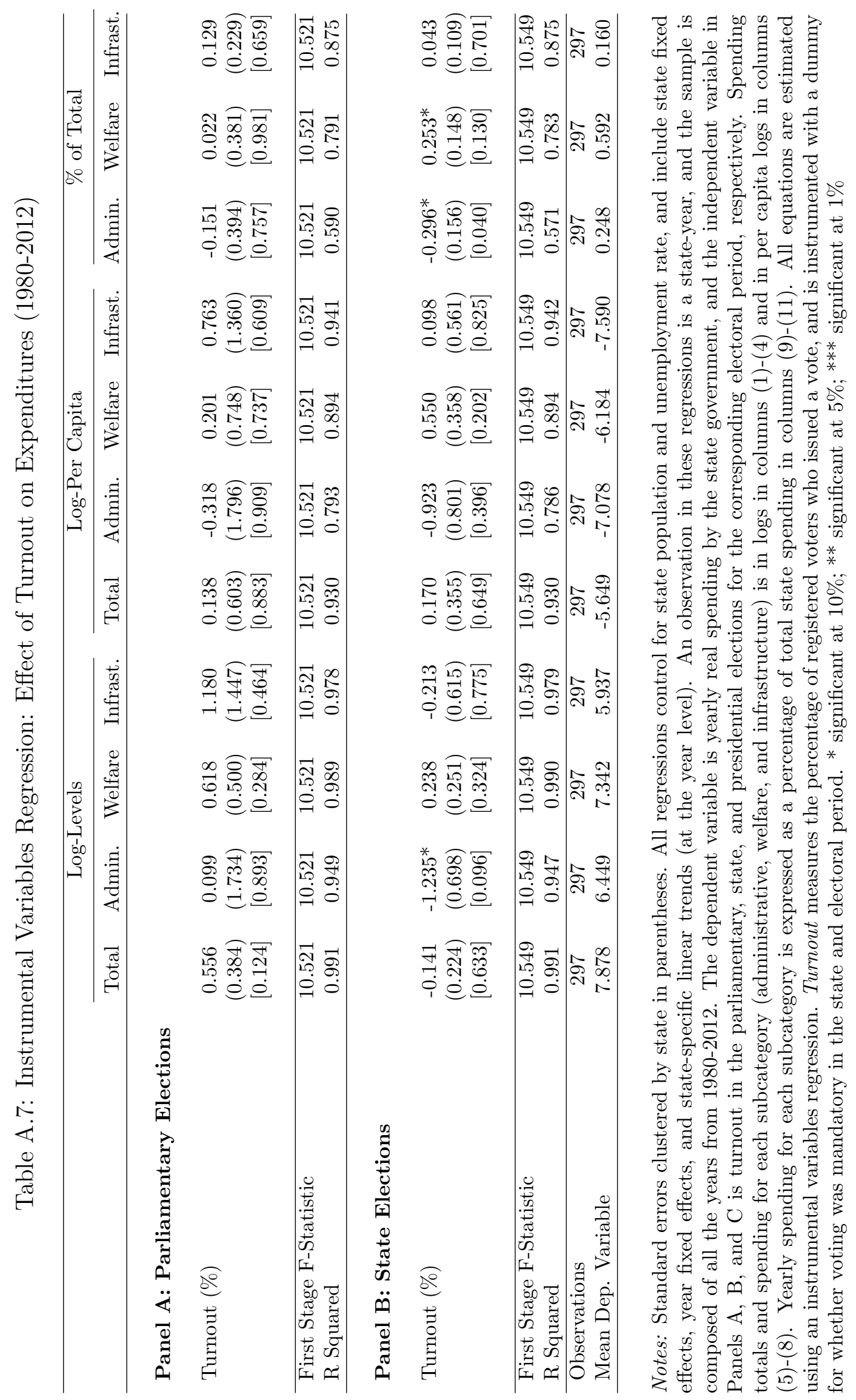




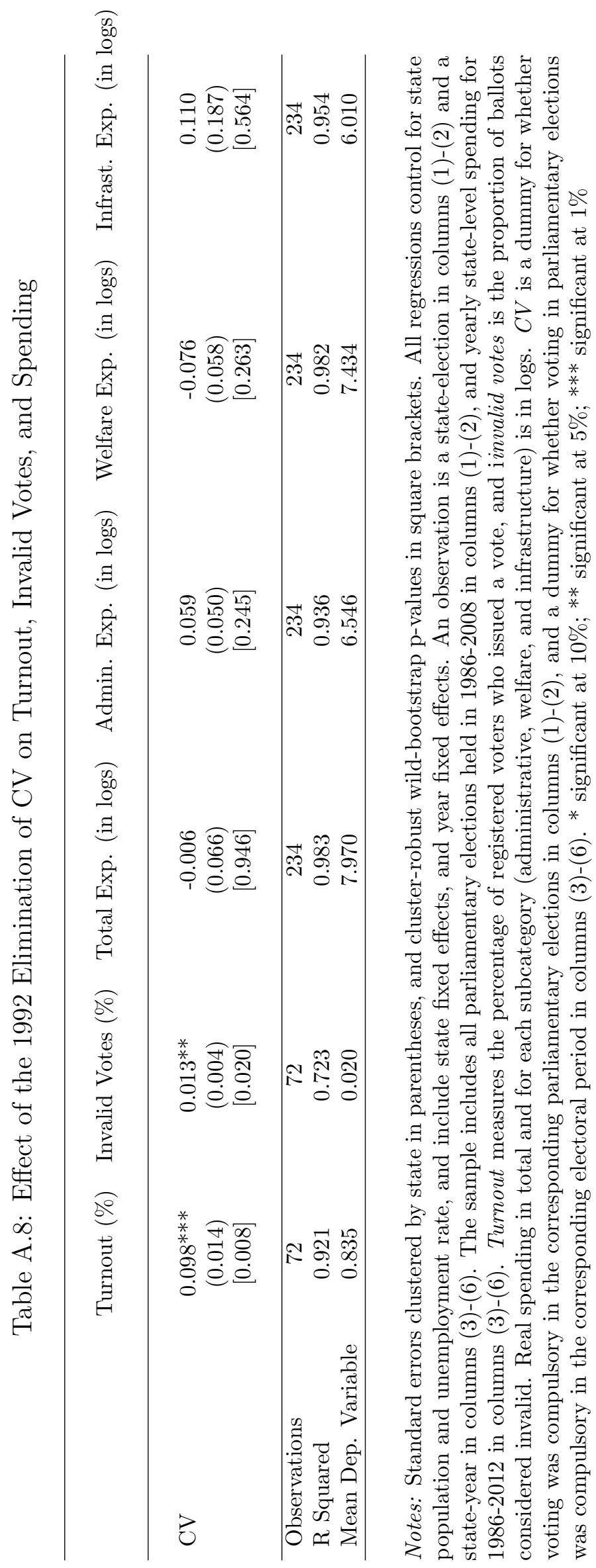


Table A.9: Robustness Check: Effect of CV on Turnout and Invalid Votes

\begin{tabular}{|c|c|c|}
\hline & Turnout (\%) & Invalid Votes (\%) \\
\hline $\mathrm{CV}(\mathrm{t}+1) *$ Parliamentary & $\begin{array}{l}-0.017 \\
(0.020) \\
{[0.348]}\end{array}$ & $\begin{array}{l}-0.000 \\
(0.005) \\
{[0.919]}\end{array}$ \\
\hline $\mathrm{CV}(\mathrm{t}) *$ Parliamentary & $\begin{array}{c}0.098^{* *} \\
(0.037) \\
{[0.018]}\end{array}$ & $\begin{array}{c}0.009 \\
(0.007) \\
{[0.246]}\end{array}$ \\
\hline CV $(\mathrm{t}-1) *$ Parliamentary & $\begin{array}{l}-0.011 \\
(0.020) \\
{[0.573]}\end{array}$ & $\begin{array}{c}0.003 \\
(0.003) \\
{[0.168]}\end{array}$ \\
\hline $\mathrm{CV}(\mathrm{t}+1) *$ State & $\begin{array}{l}-0.003 \\
(0.014) \\
{[0.869]}\end{array}$ & $\begin{array}{c}0.001 \\
(0.008) \\
{[0.895]}\end{array}$ \\
\hline $\mathrm{CV}(\mathrm{t}) *$ State & $\begin{array}{l}0.109^{*} \\
(0.049) \\
{[0.000]}\end{array}$ & $\begin{array}{l}0.018^{*} \\
(0.008) \\
{[0.056]}\end{array}$ \\
\hline $\mathrm{CV}(\mathrm{t}-1) *$ State & $\begin{array}{l}-0.017 \\
(0.055) \\
{[0.761]}\end{array}$ & $\begin{array}{l}-0.007 \\
(0.004) \\
{[0.270]}\end{array}$ \\
\hline $\mathrm{CV}(\mathrm{t}+1) *$ Presidential & $\begin{array}{l}-0.026^{*} \\
(0.012) \\
{[0.034]}\end{array}$ & $\begin{array}{l}-0.003 \\
(0.006) \\
{[0.613]}\end{array}$ \\
\hline $\mathrm{CV}(\mathrm{t}) *$ Presidential & $\begin{array}{c}0.078^{* * *} \\
(0.017) \\
{[0.006]}\end{array}$ & $\begin{array}{l}0.012^{*} \\
(0.006) \\
{[0.032]}\end{array}$ \\
\hline $\mathrm{CV}(\mathrm{t}-1) *$ Presidential & $\begin{array}{l}-0.028 \\
(0.017) \\
{[0.358]}\end{array}$ & $\begin{array}{l}-0.001 \\
(0.004) \\
{[0.741]}\end{array}$ \\
\hline $\begin{array}{l}\text { Observations } \\
\text { R Squared } \\
\text { Mean Dep. Variable (if } \mathrm{CV}=0)\end{array}$ & $\begin{array}{c}388 \\
0.935 \\
0.844\end{array}$ & $\begin{array}{c}391 \\
0.853 \\
0.020\end{array}$ \\
\hline
\end{tabular}

Notes: Standard errors clustered by state in parentheses, and cluster-robust wild-bootstrap p-values in square brackets. All regressions control for state population and unemployment rate, and include state fixed effects, year fixed effects, state-specific linear trends (at the election level), and election type dummies. An observation in these regressions is a state-election, and the sample includes all parliamentary, state, and presidential elections from 1949-2010. Turnout measures the percentage of registered voters who issued a vote, and invalid votes is the proportion of ballots considered invalid. $C V$ dummies and their lags and leads indicate whether voting was mandatory in a state and election. ${ }^{*}$ significant at $10 \% ;{ }^{* *}$ significant at $5 \%$; ${ }^{* *}$ significant at $1 \%$ 


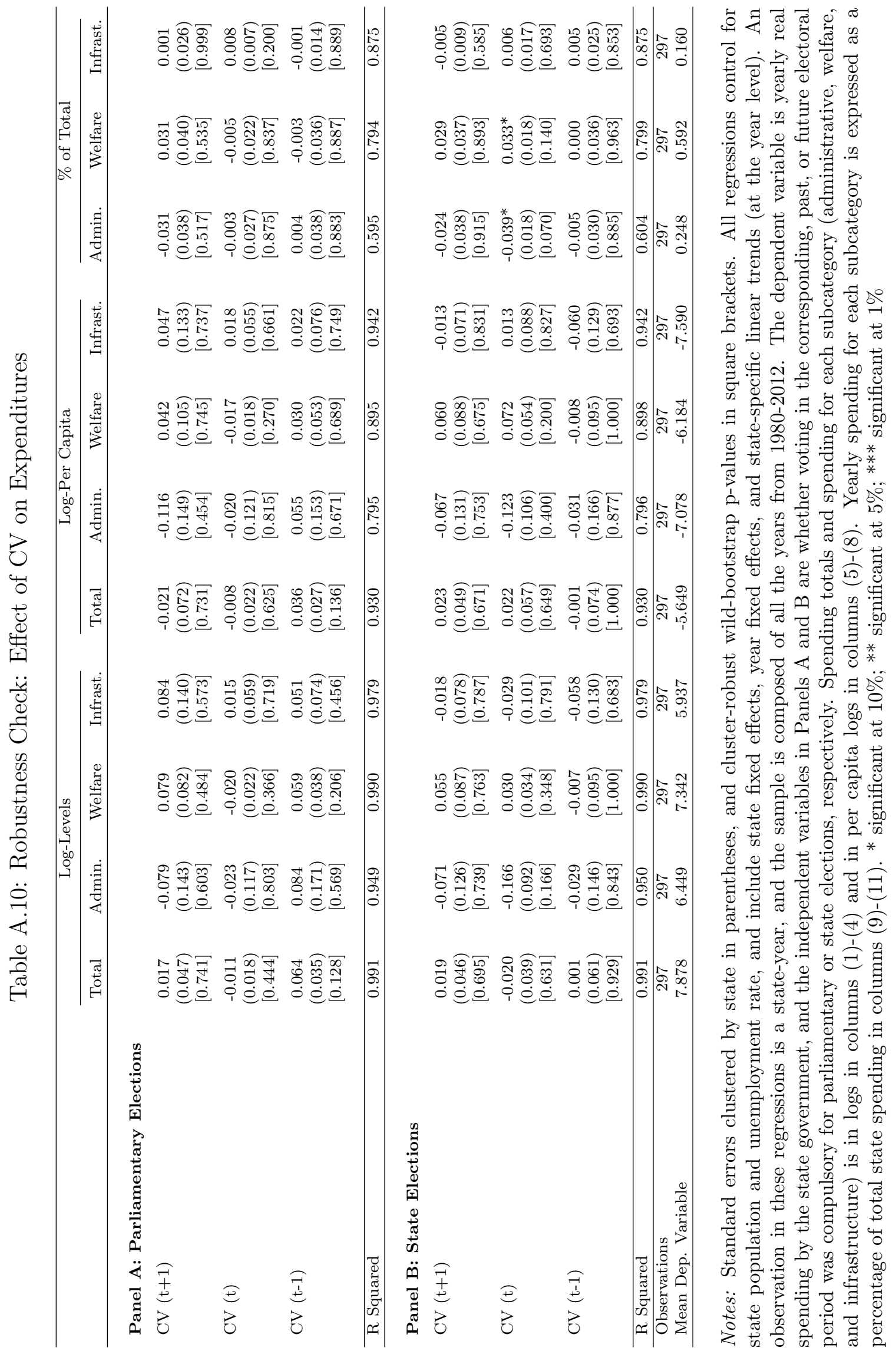




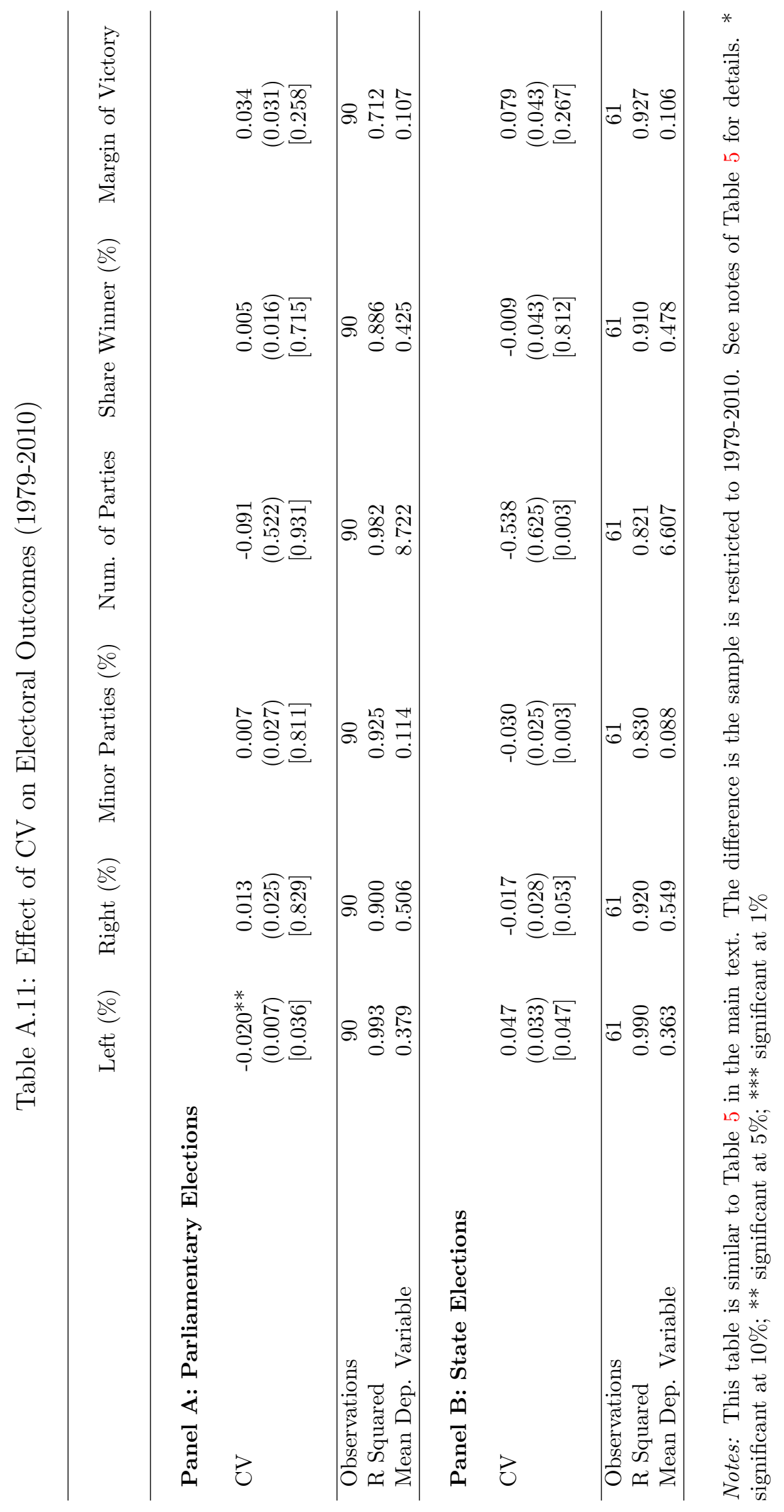




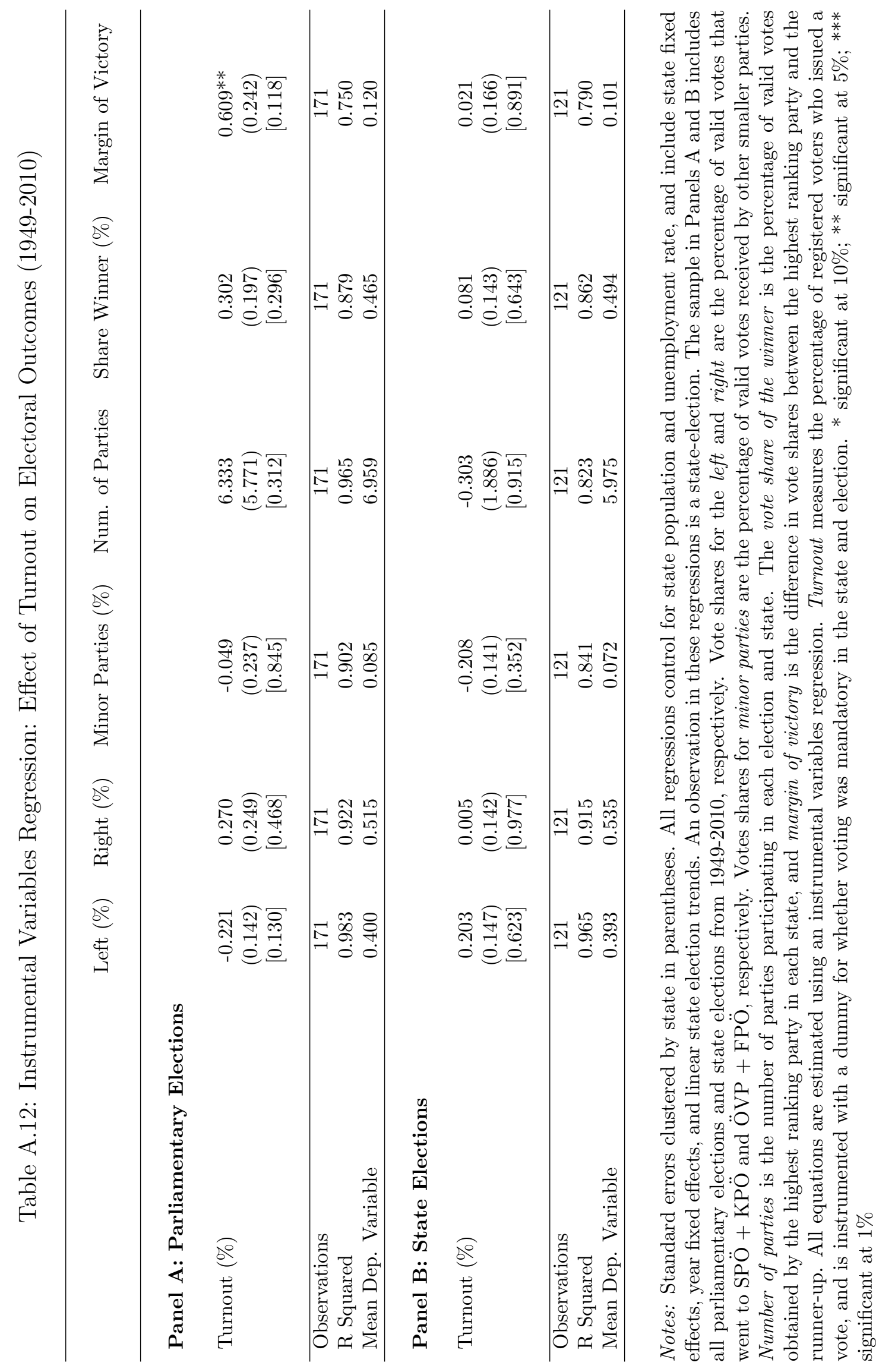




\section{Appendix B Further Background on CV in Austria}

\section{Appendix B.1 Compulsory Voting in Austria before 1945}

The debate concerning the introduction of CV in Austria goes back to the enfranchisement of women in 1918. Conservative parties feared that their women supporters would not be as politically active and easy to mobilize as women who supported the Social Democrats, who had advocated for universal voting rights. CV was therefore seen as an instrument for conserving their power. Informal accounts mention that during the debates regarding the implementation of CV, conservatives put forward the argument that participation in political decisions and public life was not only a right but a duty of every citizen. ${ }^{36}$ Social Democrats were against its implementation, and thus a compromise was reached, leaving the prerogative of instating mandatory voting to the states. In 1919, before the elections for the Constituent National Assembly, provisions for CV were made in Vorarlberg and Tyrol. ${ }^{37}$ When the 1920 constitution was amended in December 1929, it became up to each state to decide whether voting was compulsory or not in national parliament and state parliament elections. ${ }^{38}$

The 1920 constitution, which was parliamentary in nature, underwent other important changes in 1929. The responsibilities of the president were broadened, and the election of the president became determined by popular vote rather than by decision of the members of the legislature. Furthermore, voting in presidential elections became mandatory in the whole country. ${ }^{39}$ Although the first election was supposed to occur in 1931, due to the worldwide economic depression, political parties decided to suspend the elections and reelect the incumbent president. In May 1934, the Fascist ruling party repealed the 1929 constitution, but after World War II, in May 1945, the 1920 constitution (with its 1929 amendments) was reinstated. Thus, both the country-wide provisions for mandatory voting in presidential elections and the state-determined CV in national parliament and state parliament elections were restored. In spite of this, and probably due to the post-war chaos, the 1945 national and state parliament elections were carried out according to a national law made specifically for this election. ${ }^{40}$ Thus, voting in the 1945 elections was optional for individuals in all states, including Tyrol and Vorarlberg. Only in the next election for national and state parliament, both held in 1949, did Vorarlberg and Tyrol re-implement CV. Furthermore, the state of Styria also enacted its own CV law for these elections. ${ }^{41}$

\footnotetext{
${ }^{36} \mathrm{http}: / /$ www .onb.ac.at/ariadne/projekte/frauenwaehlet/Raum07.html, last accessed March 16, 2016

${ }^{37}$ http://www . parlament.gv . at/PERK/HIS/WAHL/REGEL/index.shtml, last accessed March 16, 2016.

${ }^{38}$ Federal Constitution of December 1929 (B-VG) Articles 26 (1) and 95 (1)-(2).

${ }^{39}$ Federal Constitution of December 1929 (B-VG) Article 60 (1).

${ }^{40}$ Election Law 198 (Wahlgesetz) from October 1945.

${ }^{41}$ Styria Law 30 from July 11, 1949.
} 


\section{Appendix B.2 Fines for Abstention under Compulsory Voting}

Maximum fines for abstention in presidential and parliamentary elections with CV were established by the National Parliament, whereas state parliaments had the authority for establishing maximum fines for non-voting in state elections. In all three election types, however, the actual fine amounts and their enforcement were left to local governments. As described in Section 2.2, abstention penalties were extremely rare, since the law allowed for a wide range of excuses for not voting. ${ }^{42}$ Although there is no comprehensive information on the exact fines that individuals were charged with in the few cases in which these were enforced, anecdotal evidence suggests that fines were in fact much lower than the ceilings set by law.

Since each state had the authority for establishing maximum fines for non-voting in state elections, there was substantial variation across states (and time) in these maximum fines. When CV for state elections was established in Vorarlberg in 1919, fines varied depending on the socioeconomic status of the violator, ranging from 1 kronor(0.9 US dollars) to 50 Austrian kronor (44 USD). ${ }^{43}$ The law establishing the value of these fines was modified over time, and in 1988, for example, fines were capped at 10,000 schillings (1,413 USD). ${ }^{44}$ Although maximum penalties were high, this ceiling was not binding, and in practice fines were significantly lower. Only in very few cases were non-voters effectively fined, with fines around 300-500 schillings ( 42-71 USD). Non-voters from Vorarlberg were asked by the mayor of their municipality to provide reasons for abstention, but were not required to provide any official proof. Those who did not comply with this request within a week and were reported to the authorities were granted an extra two weeks to provide a justification for their abstention. In 1949, punishment for abstention in state elections in Styria was set at a maximum of 1,000 schillings and four weeks of imprisonment, following the maximum sanctions for abstention in federal elections. ${ }^{45}$ In the case of Tyrol, maximum fines for abstention in state parliament elections were always kept at 1,000 schillings, ranging due to inflation from around 506 USD in 1958 to 102 USD in 2002 when CV was eliminated (all in December 2015 values). ${ }^{46}$ While the aforementioned states formally sanctioned abstention in state parliament elections, the enactment of $\mathrm{CV}$ in Carinthia in 1986 only explicitly set a punishment for abstention in federal elections (matching the corresponding federal laws). For state parliament elections, the law only states that

\footnotetext{
${ }^{42}$ Private correspondence between the authors and government officials confirmed that fines were enforced in only a handful of cases. Additionally, the website http://www.idea.int/vt/compulsory_voting.cfm describes the sanctions for not voting as being "weakly enforced" (accessed March 16, 2016).

${ }^{43}$ Vorarlberg State Law enacted in January 27, 1919, Article 2.

${ }^{44}$ Vorarlberg State Law number 60 enacted in December 14, 1988, Article 73(3). All figures in schillings are expressed in nominal terms. To express these in current dollars, the schilling values are updated to their 2015 value using the Austrian CPI, and then converted to dollars using the appropriate exchange rate.

${ }^{45}$ Styria State Law enacted in July 11, 1949, Article 1(3).

${ }^{46}$ Tyrol State Law number 27, enacted in July 29, 1949; Tyrol State Law number 20, enacted in July 5, 1965; and Tyrol State Law number 54, enacted in November 21, 1988.
} 
abstainers must be sent a message from the government informing them about the importance of voting under a democratic state. ${ }^{47}$

Sanctions for abstention in presidential elections were initially capped at 1,000 schillings ${ }^{48}$ ( 506 USD). In 2004, the last presidential election in which any state had CV, this sanction could amount to 72 euros $\left(\sim 97\right.$ USD in December 2015). ${ }^{49}$ The maximum fine for non-voting in parliamentary elections was also initially set at 1,000 schillings, but unlike presidential elections, the national law regulating parliamentary elections also established that failure to settle this fine was punishable by up to four weeks in jail. ${ }^{50}$ In 1971 , maximum sanctions for abstention in parliamentary elections were increased to 3,000 schillings (992 USD), but maximum imprisonment for not paying the fines was lowered to two weeks. ${ }^{51}$

\section{Appendix B.3 Further Information on Elimination of CV Starting in 1994}

Anecdotal information from the state legislature discussions on the elimination of CV shows that this repeal was triggered by the de facto null enforcement of the fines, and by the fact that parliamentary CV had already been repealed in 1992. Specific references can be found in Styria's state parliament session of January 26, 1993, and Tyrol's state parliamentary session of June 30, 2004.

\section{Appendix C Additional Discussion and Results}

State spending. Beyond sharing of responsibilities, decision-making powers may also be shared across different levels of government for closely related areas (Fuentes et al., 2006). In the description in Section 2.1 in the main text, we focus on the components of fiscal transfers. We use information from Tables 1 and 2 of Lehner (1997) to do our calculation about the share of transfers that are earmarked. It should be noted that federal transfers make up a majority but not all of state-level spending (Lehner, 1997) and there are also changes over time. Other sources focus on breakdowns for revenues instead of transfers. For example, Fuentes et al. (2006) report that earmarked revenues are about one-third of total state revenues (net of additional fiscal arrangements between state and municipal governments) (Fuentes et al., 2006, p. 11). OECD (1997) notes that "the proportion of their gross revenue which the [states] can spend at their own discretion rises to about 40 per cent" (this again focusing on revenues

\footnotetext{
${ }^{47}$ Carinthia state law issued in April 7, 1986, Article 3(3).

${ }^{48} 1957$ Federal Presidential Election Law, Article 25.

${ }^{49} 2002$ Federal Presidential Election Law, Article 23(3).

${ }^{50}$ Federal Parliament Election Law, Article 105 (3).

${ }^{51}$ Article 109 (3) of the 1971 Federal Parliament Election Law.
} 
instead of transfers). Our point in the main text is that Austrian states still have autonomy over a considerable share of the budget (in an absolute sense) and that our analysis would be able to pick up important changes in state-level spending were they to arise. ${ }^{52}$

\section{Effect of the 1992 Elimination of CV on Turnout, Invalid Votes, and Spending.} Table A.8 show the results of our difference-in-difference regression limiting our sample to the parliamentary elections in the electoral periods between 1986 and 2011, in which the only change in CV laws was federally enacted in 1992. This law forced Vorarlberg, Styria, Tyrol and Carinthia to eliminate $\mathrm{CV}$ in parliamentary elections. ${ }^{53}$ The magnitude and statistical significance of the results is remarkably similar to those shown in Tables 3 and 4 . The repeal of CV in 1992 causes a decrease in turnout in parliamentary elections of 9.8 percentage points, and an increase in invalid ballots of 1.3 percentage points. Likewise, in neither of our specifications do we find that $\mathrm{CV}$ affects fiscal policy. Due to the short time period covered in these regressions, we do not include state specific trends. Controlling for state-specific time trends, the repeal of CV in 1992 causes a decrease in turnout of 3.75 percentage points (significant at the $10 \%$ level), and an increase in the proportion of invalid ballots by 0.20 percentage points, although the latter is statistically insignificant. Furthermore, the results for our spending regressions are quantitatively similar when we control for state trends. These results suggest that any other changes in CV (besides the 1992 one) are unlikely to be correlated with trends in the main dependent variables.

Electoral Outcomes. As discussed in the main text, the SPÖ and ÖVP are the two major parties in Austria. We define "right-wing" parties as ÖVP and FPÖ and "left-wing" parties as SPÖ and KPÖ, although it is somewhat arbitrary to include the KPÖ in this list. The variables for the four parties are defined using the column headers marked "OEVP," "SPOE," "FPOE," and "KPOE" from the election data spreadsheets (which a research assistant created from the Ministry of Interior yearbooks). Thus, we ignore votes gained when smaller parties have run under different names and groupings over time. At the start of the sample period, there was the "Electoral Party of Independents," which was the predecessor to the FPÖ (Manoschek, 2002). We have defined this party as part of "minor parties," but our conclusions are robust

\footnotetext{
${ }^{52}$ Our point is not that Austrian states have a high level of fiscal autonomy compared to states in other federal countries (e.g., Austrian states lack significant tax powers (Fuentes et al., 2006)).

${ }^{53}$ The estimation equation is given by: $y_{s t}=\alpha_{0}+\alpha_{1} C V_{s} * \operatorname{Pre}_{t}+X_{s t} \beta+\delta_{s}+\nu_{t}+\epsilon_{s t}$. As in our previous specifications, $y_{s t}$ is an election outcome variable or expenditures in state $s$ and year $t$; $C V_{s}$ is a dummy variable indicating whether voting was compulsory in state $s$ before the 1992 constitutional amendment, $\mathrm{Pre}_{t}$ is a dummy for the elections before 1992, $X_{s t}$ is a vector of state-year covariates (population and the unemployment rate), $\delta_{s}$ and $\nu_{t}$ are state and year fixed effects and $\epsilon_{s t}$ is the error term. Our interest lies in the coefficient that measures the difference-in-difference between states with and without $\mathrm{CV}$, before and after the reform, $\alpha_{1}$. For comparison with previous tables, we introduce the "Pre" instead of "Post" dummy because after 1992, CV was repealed, rather than introduced.
} 
to including it in the right-wing parties. In addition, we count the "linksblock" (left bloc) as part of minor parties. Our conclusions are also robust to defining the "left-wing" solely as the SPÖ (i.e., not counting the KPÖ as part of "left-wing" parties).

For our analysis of electoral outcomes, we do not study presidential elections because parties do not run as separate entities in those races. Instead, they form coalitions that cross party lines and change over time, making it impossible to identify the proportion of votes for right and left wing parties. In 1974, for example, the candidate nominated by the socialist SPÖ won the presidential election. This candidate was reelected in the 1980 elections, where he received support from the SPÖ but also from the right-wing ÖVP party.

With respect to our state and parliamentary election regressions, although we only report the results considering vote shares for left $(\mathrm{SPÖ}+\mathrm{KPÖ})$ and right wing (ÖVP + FPÖ) parties, we also run regressions using the individual vote shares of these parties and find no effect. We also checked whether there was any impact on voter polarization, and find that there is no effect of CV on the sum of vote shares for the two main parties (SPÖ and ÖVP).

CV Effects by Heterogeneity in Turnout. An additional test of our hypothesis is to explore the heterogeneity of the effect between low vs. high turnout states. If it is indeed the case that voters who turn out to vote only because of the introduction of CV do not have different preferences than those who vote despite the absence of $\mathrm{CV}$, this effect should not depend on the baseline level of turnout, or even on the size of the "first stage" (i.e., the effect of $\mathrm{CV}$ on turnout). The results (available upon request) show that the effect of $\mathrm{CV}$ is larger in low turnout states, though the effect is not always statistically significant. This result is consistent with Funk (2007), who documents that the effect of the abolition of CV (a law with low or no sanctions) in Swiss cantons is larger in places with lower baseline turnout. She argues that low baseline turnout is related to a social norm, thus in places in which the social norm was stronger, the effects of an expressive law were undermined. However, despite the heterogeneity that shows up in the first stage, the effect of $\mathrm{CV}$ on the composition and level of spending at the state level remains very close to zero and statistically insignificant in most cases.

Further Details on Elections. In Austria, elections occur for five bodies/offices: (1) The National Council (henceforth "parliamentary elections"), (2) State parliaments ("state elections"), (3) Federal President ("presidential elections"), (4) Municipal council, and (5) The European Parliament. Throughout the paper, we focus exclusively on the first three. In 2007, the voting age in Austria was lowered to 16 for nationwide elections, referenda, and plebiscites (Kritzinger et al., 2013; Wagner et al., 2012). 
CV and Transmission of Political Information. One way that CV could affect turnout and other outcomes is by affecting political information. When voting is compulsory, this may change the incentive of voters to acquire political information and/or may also affect the incentive of parties to transmit information in political campaigns. To examine whether CV affects voters' acquisition of information, we repeated the first regression in Table 6, but using newspaper reading as the outcome instead of turnout. We found no significant relation between $\mathrm{CV}$ and newspaper reading, though we recognize this is only a coarse measure of information acquisition. We do not have data on the campaign activities of political parties, so we cannot examine whether parties change their behavior. Overall, transmission of political information could be an important mechanism for our results, but it is difficult for us to examine this empirically.

Turnout disparity by income. Beyond the factors discussed in the Conclusion as reasons why the impacts of CV may vary by country, another factor is how large are the disparities in CV by income. See Mahler et al. (2014) and http://www.politico.com/magazine/story/ 2015/01/income-gap-at-the-polls-113997 (last accessed in September 2016) for further evidence on disparities. Such disparities could affect how CV affects multiple outcomes, including turnout, spending, and electoral outcomes.

\section{References for the Appendix}

Fuentes, Andrew, Eckhard Wurzel, and A. Wörgötter, "Reforming Federal Fiscal Relations in Austria," 2006. OECD Economics Department Working Papers, No. 474, OECD Publishing.

Funk, Patricia, "Is there an Expressive Function of Law? An Empirical Analysis of Voting Laws with Symbolic Fines," American Law and Economics Review, 2007, 9 (2), 135-159.

Kritzinger, Sylvia, Eva Zeglovits, Michael S Lewis-Beck, and Richard Nadeau, The Austrian Voter, Vandenhoeck \& Ruprecht, 2013.

Lehner, Gerhard, Die Bundesländer im Finanzausgleich, WIFO: Austrian Institute for Economic Research, 1997.

Mahler, Vincent A, David K Jesuit, and Piotr R Paradowski, "Electoral Turnout and State Redistribution A Cross-National Study of Fourteen Developed Countries," Political Research Quarterly, 2014, 67 (2), 361-373.

Manoschek, Walter, "FPO, OVP, and Austria's Nazi Past," in Ruth Wodak and Anton Pelinka, eds., The Haider Phenomenon in Austria, Transaction Publishers, 2002. 
OECD, "Managing across Levels of Government: Austria," 1997, pp. 93-106.

Wagner, Markus, David Johann, and Sylvia Kritzinger, "Voting at 16: Turnout and the quality of vote choice," Electoral studies, 2012, 31 (2), 372-383. 